\title{
MESOSCOPIC TO MICROCROPIC STRUCTURES ASSOCIATED WITH THE WANNI COMPLEX/HIGHLAND COMPLEX BOUNDARY SHEAR ZONE IN SRI LANKA
}

\author{
LALINDRA V. RANAWEERA ${ }^{1, *}$, K.V. WILBERT KEHELPANNALA ${ }^{2, *}$ \\ ${ }^{1}$ Department of Natural Resources, Faculty of Applied Sciences, Sabaragamuwa University \\ of Sri Lanka, Belihuloya 70140, Sri Lanka \\ ${ }^{2}$ Department of Geology, Faculty of Science, University of Botswana, Private Bag UB 00704, \\ Gaborone, Botswana
}

*Corresponding authors'e-mails: laliwr@appsc.sab.ac.lkand kvwilbert@hotmail.com

(Received 29 $9^{\text {th }}$ July 2019; accepted $6^{\text {th }}$ October 2019)

\begin{abstract}
In this study, we report mesoscopic and microscopic structures in sheared rocks associated with the Wanni Complex/Highland Complex boundary shear zone (WHBSZ) which represents a deep part of a granulite-facies, crustal-scale ductile shear zone in the Proterozoic basement of Sri Lanka. Normal khondalitic mylonites, spinel-bearing khondalitic mylonites, semipelitic mylonites and metagranitoid mylonites (striped gneisses) found along the WHBSZ show mesoscopic to microscopic scale shear sense indicators such as $S$ - $C^{\prime}$ fabrics, rotated garnet porphyroblasts, $\delta$-type and $\sigma$-type asymmetric objects, asymmetric folds and sheath folds. These asymmetric mesoscopic to microscopic structures indicate that the dominant deformation along the WHBSZ is non-coaxial ductile flow and that the WC has been emplaced from NNW (present orientation) on top of the HC. The presence of mylonites and ultramylonites along the WHBSZ suggests severe grain size reduction during the shearing. All the mylonites studied along the boundary shear zone have developed a mylonitic foliation, defined by quartz plates and ribbons, elongated and recrystallized fine-grained aggregates of feldspar, and a very strong stretching lineation mostly defined by c-axis of sillimanite and stretched quartz and elongated aggregates of other minerals. All the mesoscopic and microscopic structures suggest that the WHBSZ has formed during the second phase of $\mathrm{D}_{2}$ non-coaxial deformation accompanying high-temperature (HT) to ultrahigh temperature (UHT) granulite facies metamorphism related to the first collision between the WC and the HC. This study emphasizes that careful study of granulite facies mylonites may provide reliable shear sense indicators for understanding the nature and kinematics of deep crustal shear zones.
\end{abstract}

Keywords: Granulites, Microstructures, Mylonites, Shear Sense Indicators, Sri Lanka

\section{INTRODUCTION}

Crustal-scale ductile shear zones are an important type of paleo movement zones and provide information about the nature and types of deformation at deep crustal levels associated with motions of lithospheric fragments (e.g. Passchier, 1988; Passchier and Coelho, 2006; Platt and 
Behr, 2011; Fossen et al., 2017). Moreover, largescale Precambrian shear zones are important for understanding kinematic models for large-scale tectonic reconstructions (Passchier and Coelho, 2006) and have been used for linking continental fragments across paleo oceans in reconstructions of supercontinents such as Gondwana (e.g. Katz and Premoli, 1979; Yoshida et al., 1992, 1999; Kriegsman, 1995; Braun and Krigsman, 2003; Chetty, 1996; Chetty and Bhaskar Rao, 2006; Santosh et al., 2009; Osanai et al., 2016a). However, without ascertaining the nature, associated microscopic to mesoscopic structures and sense of shearing of such crustal-scale shear zones and their strain involved, it is impossible to understand the importance of these major structures in modelling large-scale paleo motions and in the use of reconstruction of supercontinents. Of these, shear sense indicators play a crutial role in understanding and determining motions along ductile shear zones (e.g. Fossen et al., 2017 and references therein). Although the use of shear sense indicators for determining the sense of shear for low-grade shear zones has been well established, kinematic analysis of ductile shear zones in granulite terrains, such as Sri Lanka, is not straight forward because of lack of clear asymmetric structures (e.g. Passchier and Coelho, 2006).

The Wanni Complex/Highland Complex boundary shear zone (WHBSZ) in Sri Lanka is an excellent example for such deep crustal shear zones, along which two contrasting crustal blocks - namely, the Wanni Complex and the Highland Complex - are welded together (e.g. Kehelpannala, 1991, 1997, 2003), and provides ample evidences for deep crustal movements associated with plate collision during Gondwana assembly (e.g. Kehelpannala, 1997, 2003, 2004; Kröner et al., 2003). Moreover, it has been shown that the Wanni Complex/Highland Complex boundary is a suture zone (Kehelpannala, 1997, 2003, 2004; Kehelpannala and Ranaweera, 2007; Ranaweera, 2008), now exposed as a crustal-scale ductile shear zone, that formed under high-temperature (HT) to ultrahigh temperature (UHT) granulite facies conditions (Kehelpannala, 2016a). Therefore, in this paper we present and describe (i) mesoscopic to microscopic structures and (ii) shear sense indicators that have formed under high-temperature (HT) to ultrahigh temperature (UHT) granulite facies conditions along the Wanni Complex/Highland Complex boundary shear zone (WHBSZ) and ascertain their importance in understanding the nature of motions of lithospheric fragments at deep crustal levels during Neoproterozoic.

\section{LITHOTECTONIC UNITS OF SRI LANKA}

The Neoproterozoic to Palaeoproterozoic basement of Sri Lanka occupies a key position in Gondwana, and its geological, geochronological and tectonothermal evolution plays a significant role in understanding the processes that led to the amalgamation of the central part of the supercontinent (e.g. Kriegsman, 1995; Kehelpannala, 1997, 2004; Kröner et al., 2003, 2013; Santosh et al., 2014; Dharmapriya et al., 2016). Early workers (Kröner et al., 1991; Cooray, 1994) subdivided the basement of Sri Lanka into four lithotectonic units as (i) the Wanni Complex (WC), (ii) the Kadugannawa Complex (KC), (iii) the Highland Complex (HC) and (iv) the Vijayan Complex (VC). However, on the basis of the similarities in lithology, structures, $\mathrm{Nd}$ model ages and U-Pb zircon ages (Milisenda et al., 1988; Kröner et al.,1991) of the Wanni and Kadugannawa Complexes, Kehelpannala $(1991,1997)$ included the $\mathrm{KC}$ in the $\mathrm{WC}$ and considered the former as part of the latter. Subsequent studies by Milisenda et al. (1994), Kröner et al. (2003) and Willbold et al. (2004) on geochronology, geochemistry and $\mathrm{Sm}-\mathrm{Nd}$ isotopic systematics confirmed that the $\mathrm{KC}$ is part of the WC. Recently, Santosh et al. (2014) speculated that the KC is part of a disrupted huge arc magma chamber that was exhumed and transposed along the margin of the $\mathrm{WC}$, rejecting the idea that the $\mathrm{KC}$ is part of the WC. More recently, however, Kehelpannala (2016b), based on field evidence in several areas of the WC surrounding the $\mathrm{KC}$ and on geochronological evidence for multiple intrusions of the mafic rocks of the KC (Kröner et al., 2003; Willbold et al., 2004), once again showed that the KC 
is indeed part of the $\mathrm{WC}$, ruling out the idea that the $\mathrm{KC}$ represents an exhumed magma chamber (Santosh et al., 2014). Kehelpannala (2016b) further argued that, it is not required to separate the $\mathrm{KC}$ from the WC as both terrains bear similar lithologies, structures, emplacement ages, isotopic characteristics and protolith ages, and thus the former should be included in the latter as already considered by Kehelpannala $(1991,1997)$ and Milisenda et al. (1994). Therefore, in this paper we follow the geological subdivision of Kehelpannala (1997), namely, from west to east, the Wanni Complex (WC), the Highland Complex (HC) and the Vijayan Complex (VC) (Fig. 1).

For complete understanding of the nature of the above three lithotectonic units and their processes of amalgamation during late Neoproterozoic, forming one crustal fragment (Sri Lanka and its possible counter parts), it is important to unravel the nature of their boundaries. Although the geographical position of the HC/VC boundary is relatively well-understood, its actual nature has yet to be established (Kehelpannala, 2016a). According to the available literature, $\mathrm{HC} / \mathrm{VC}$ boundary is considered as a sub-horizontal thrust zone with HC is moving eastward over the VC (Hatherton et al., 1975; Vitanage, 1985; Kröner et al., 1987, 2013; Milisenda et al., 1988; Voll and Kleinschrodt, 1991; Büchel, 1994; Kleinschrodt, 1994, 1996; Kriegsman, 1995; Tani, 2002; Kehelpannala, 1997, 2003). However, recent reconnaissance field studies carried out by Kehelpannala (unpublished data) in the granulite outliers occurring in the areas surrounding Buttala, Kataragama and Kuda Oya and the areas NE, E and SE of Mahiyangana strongly stress the need of revisiting and revising the nature and the geographical extent of the HC/VC contact zone (Kehelpannala, 2016a). Although the Wanni and Highland Complexes were identified as separate lithotectonic units based on lithology, U-Pb zircon and Nd-model ages, and metamorphic conditions (Milisenda et al., 1988; 1994; Kröner et al., 1991; 1994b; Hölzl et al., 1991, 1994; Cooray, 1994), the nature and the geographical position of the boundary between these units were unclear (see also Kehelpannala 2016b). After assigning the KC to the WC (Kehelpannala, 1991, 1997), the
WC/HC boundary was identified as a crustalscale ductile shear zone, especially in the central part of Sri Lanka (Kehelpannala, 1991, 1997, 2003).

The Wanni, Highland and Vijayan Complexes are three distinctly different crustal domains with contrasting geological, geochemical, isotopic and structural evolutions (Kehelpannala, 1997, 2003; Kröner et al., 2003) and were amalgamated to form the present-day Sri Lanka by two separate collisions, probably as a result of arc accretion, during the Pan-African orogeny at

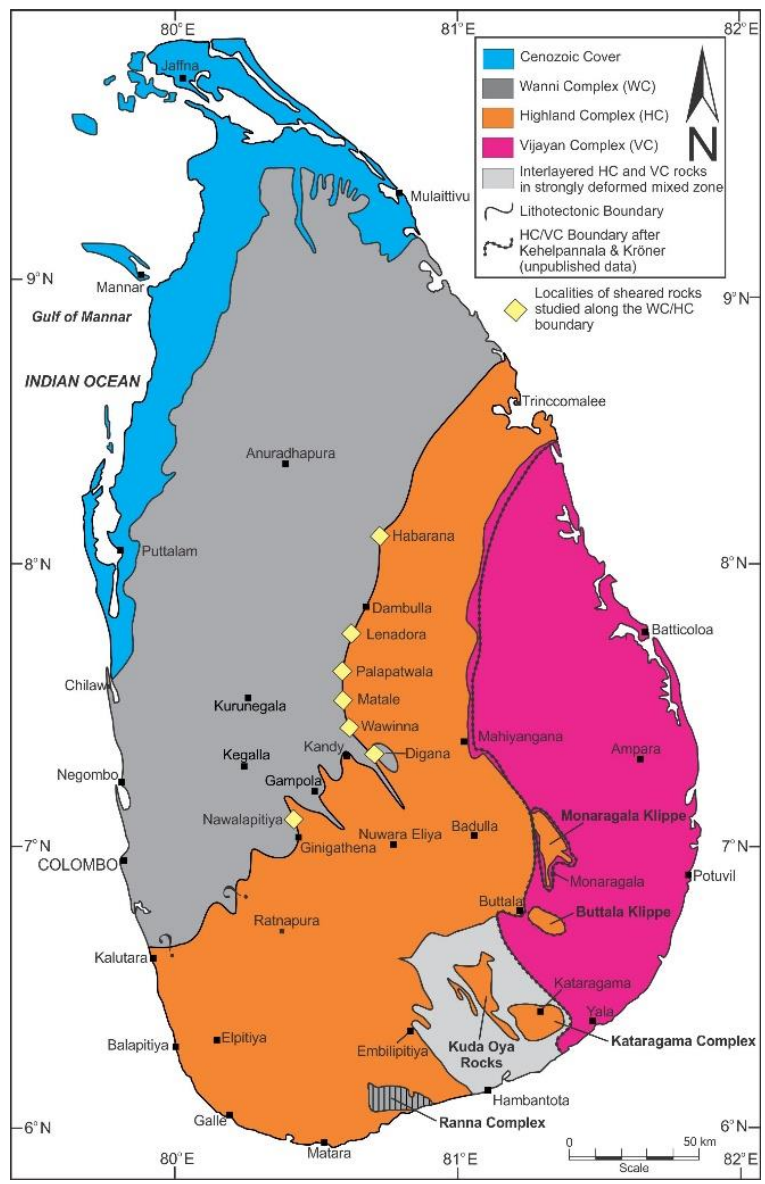

Fig.1. Lithotectonic map of Sri Lanka showing the locatilies of various mylonites studied along the WC/HC boundary. Lithotectonic boundaries are after Kehelpannala (2017).

ca 610-550 Ma (Kehelpannala, 2004). The Wanni Complex seems to have formed as part of the root zone of an Andean-type magmatic arc, whereas the Vijayan Complex may have originated as part of an island arc (Kehelpannala, 2004; Kröner et al., 2003, 2013; He et al., 2016). As this paper concentrates on the WC/HC boundary, the 
geology of both the WC and $\mathrm{HC}$ is briefly described in the following sections. Detailed accounts on the geological, geochronological and isotopic evolutions of the Vijayan Complex are given by Kröner et al. (2013) and He et al. (2016).

\section{THE WANNI COMPLEX}

As recently described by Kehelpannala (2016b), the Wanni Complex consists of supracrustal rocks, calc-alkaline I-type granitoid gneisses, pink K-feldspar granite-gneisses, charnockites and charnockitic gneisses, metagabbros, metadiorites, amphibolites, migmatites, metamonzodiorite, metamorphosed quartz monzodiorite, post-tectonic granitoids, alkaline rocks, carbonatite, and a suite of syenites, quartz syenites, monzonites and quartz monzonites of metasomatic origin (see also Kehelpannala, 2007a). The above supracrustal rocks were intruded by a variety of granitoids and mafic rocks between $\sim 1100$ Ma and $\sim 50$ Ma ago (Kröner et al., 1987, 1994b, 2003; Baur et al., 1991; Hölzl et al., 1994; Kröner and Jaeckel, 1994; Santosh et al., 2014). Kehelpannala (1997, 2004, 2016b) and Kröner et al. (2003) have shown that the sediments in the WC have been derived from nearby source in the WC itself. Moreover, Kehelpannala (2016b) argues that the Neoproterozoic sedimentation in the WC may have taken place at an active environment, probably as accretionary prism sediments (Kehelpannala, 2004) derived from the then nearby rocks originated from Neoproterozoic sources and Mesoproterozoic to early Neoproterozoic magmatic rocks.

The mafic metaigneous rocks such as metadiorite, metagabbro, metapyroxenite and associated meta-anorthosite found in the WC, especially around Kandy and Mawanella, are components of the Kandy Intrusion (Kleinschrodt et al., 1991; Willbold et al., 2004) that have intruded into and interlayered with pink granite, quartzite and calc-gneiss (Kehelpannala, 1997, 2016b). These large volume of $\sim 1100-1000 \mathrm{Ma}$ and $~ 984-$ $882 \mathrm{Ma}$ igneous rocks with calc-alkaline affinities in the WC have been interpreted as products of subduction-related arc magmatisms (Pohl and Emmermann, 1991; Kröner et al., 2003; Willbold et al., 2004; Santosh et al., 2014; Kehelpannala, 2016b). These multiple mafic intrusions of the Kandy Intrusion (part of the former KC) rule out the idea of an exhumed magma chamber transposed along the margin of the WC (Santosh et al., 2014) and support the suggestion of Kehelpannala (1991) that it consists of several, possibly sheet-like, bodies that were emplaced over a period of time in the entire WC (Kleinschrodt et al., 1991; Kroner et al., 2003; Kehelpannala, 2016b). Available isotopic and geochemical data on basic rocks from the area around Kandy in the Wanni Complex clearly demonstrate that these rocks represent a deep part of a magmatic arc (Willbold et al., 2004; Santosh et al., 2014). Based on available geological, geochemical, isotopic, geochronological and structural data (e.g., Pohl and Emmermann, 1991; Kröner and Jaeckel, 1994; Kröner et al., 1994a, 2003; Milisenda et al., 1994; Kehelpannala, 1997, 2003; Willbold et al., 2004; Santosh et al., 2014), Kehelpannala (2004, 2016b) and Kröner et al. (2003) suggest that the Wanni Complex may be a root zone of a late Mesoproterozoic-Neoproterozoic Andean-type magmatic arc.

The rocks of the WC have undergone upper amphibolite to granulite-facies metamorphism. Pressure and temperature conditions of peak metamorphism in the Wanni Complex rocks exposed around Kandy and Mawanella are 6-6.6 kbar and $700^{\circ}-730^{\circ} \mathrm{C}$, respectively (Schenk et al., 1991; Kehelpannala, 2016b). However, based on orthopyroxene/clinopyroxene thermometry, Kleinschrodt et al. (1991) estimated temperature of $780^{\circ}-840^{\circ} \mathrm{C}$ for the above areas, which probably records the peak temperature of the granulite-facies metamorphism (Kehelpannala, 2016b). Temperature calculated by Malaviarachchi and Takasu (2011) from pelitic gneiss and mafic rocks of the WC around Kandy yielded $750^{\circ} \mathrm{C}$ and $690^{\circ} \mathrm{C}$, respectively. Recent geothermometric estimation by Santosh et al. (2014) from two rock samples of the Kandy mafic rocks records a temperature of $700^{\circ}-770^{\circ} \mathrm{C}$. As suggested by Kehelpannala (2016b), these low temperatures probably indicate re-equilibration during retrogression (Malaviarachchi and Takasu, 2011; Santosh et al., 2014). All the above magmatic rocks and sediments have been deformed and 
metamorphosed under amphibolite to granulite facies conditions at about 620-535 Ma (Kröner and Williams, 1993; Santosh et al., 2014; Dharmapriya et al., 2016; Osanai et al., 2016a; Kehelpannala, 2016b).

\section{THE HIGHLAND COMPLEX}

The centrally located Highland Complex (HC) of Sri Lanka is sandwiched between the Wanni Complex (WC) to the NW and W and the Vijayan Complex (VC) to the E (Fig. 1; Kehelpannala, 1997, 2016a). The Highland Complex is composed of supracrustal rocks, charnockites, enderbites, some metabasites, metamorphosed gabbroic to dioritic rocks and other orthogneisses, all of which have higher Nd model ages $(2.0-3.4 \mathrm{Ga})$ than that of the rocks in the WC and VC (Milisenda et al., 1988, 1994; Kröner et al. 2003, 2013). In addition, the HC consists of Neoproterozoic mafic sills and dykes, granites, pegmatites, syenites and quartz syenites intruded into the basement (see Kehelpannala, 2007, 2016a; Santosh et al., 2014; Tsunogae et al., 2015; Kröner et al. 2017, 2018). The major metasedimentary units in the $\mathrm{HC}$ are marble, dolomitic marble, calc-silicate gneiss, metapelites (including khondalites), metasemipelites and quartzite and represent a passive continental margin sedimentary sequence (Dissanayake and $\mathrm{Mu}-$ nasinghe, 1984; Kröner et al., 1994b) of limestone, shale and sandstone/siltstone, respectively. The supracrustal lithologies are interlayered with magmatic rocks and orthogneisses consisting of recycled Palaeoproterozoic to Archaean materials (Milisenda et al., 1988, 1994; Santosh et al., 2014; Tsunogae et al., 2015; He et al., 2016; Kröner et al. 2017, 2018; Kitano et al., 2018).

The age of the sedimentation in the $\mathrm{HC}$ is currently a debatable subject. According to previous $\mathrm{U}-\mathrm{Pb}$ ages of detrital zircon from $\mathrm{HC}$ paragneisses, the deposition of precursor sediments of this complex has taken place $\sim 2$ Ga ago (Kröner et al., 1987; Baur et al., 1991; Hölzl et al., 1991, 1994). However, based on recent LA-ICPMS U$\mathrm{Pb}$ dating of zircons from some HC metasediments, Takamura et al. (2016) and Dharmapriya et al. (2016) interpreted that the depositional age of the HC sediments to be Late Neoproterozoic.
This idea of Neoproterozoic age for $\mathrm{HC}$ sediments has been challenged by Kehelpannala (2016b) and Kröner et al. $(2017,2018)$ based on recent field and geochronological evidences that support Palaeoproterozoic sedimentation in the $\mathrm{HC}$ (Kehelpannala in preparation).

These Palaeoproterozoic sediments were intruded by large volume of metagranitoids during Palaeoproterozoic (Kröner et al., 1987, 2017, 2018; Baur et al., 1991; Hölzl et al., 1994; Santosh et al., 2014) and by some Neoproterozoic felsic to mafic intrusions, either as sills or dykes, during Neoproterozoic (Baur et al., 1991; Santosh et a., 2014; Tsunogae et al., 2015; Kröner et al., 2017, 2018). All these rocks underwent high temperature to UHT granulite facies metamorphism during Neoproterozoic-Cambrian (Kröner and Williams, 1993; Sajeev et al., 2010; Santosh et al. 2014; Dharmapriya et al., 2015, 2016; Osanai et al., 2016a). The pressure and temperature of the granulite facies metamorphism, estimated based on various mineral assemblages from pelitic and mafic granulites, are $8-9 \mathrm{kbar}$ and $800-900^{\circ} \mathrm{C}$, respectively (Raase and Schenk, 1994; Schumacher and Faulhaber, 1994; Kriegsman and Schumacher, 1999; Malaviarachchi and Takasu, 2011; Dharmapriya et al., 2015). UHT granulites have been reported only from few localities in the central HC from pelitic, mafic and quartzo-feldspathic granulites (Osanai, 1989; Kriegsman and Schumacher, 1999; Osanai et al., 2000, 2006, 2016a,b; Braun and Kriegsman, 2003; Sajeev and Osanai, 2004; Sajeev et al., 2007, 2010; Malaviarachchi and Dharmapriya, 2015; Dharmapriya et al., 2016, 2017a,b), and most of these UHT granulites are located along the $\mathrm{WC} / \mathrm{HC}$ boundary shear zone (Kehelpannala, 2006, 2016a; Kehelpannala and Ranaweera, 2007; Touret et al., 2019). Pressure and temperature estimated from these UHT granulites are in the range of 9-12.5 kbar and $900-1150^{\circ} \mathrm{C}$, respectively (Kriegsman and Schumacher, 1999; Sajeev and Osanai, 2004; Osanai et al., 2006, 2016b; Sajeev et al., 2007, 2010; Dharmapriya et al., 2017a,b). 


\section{TECTONO-THERMAL EVOLUTION OF THE WANNI AND HIGHLAND COMPLEXES}

The tectono-thermal evolution of Sri Lanka at present is also a subject of discussion. Kehelpannala (2004) and Santosh et al. (2014) have put forward two contrasting plate tectonic models to explain the tectono-thermal evolution of Sri Lanka. According to the first model proposed by Kehelpannala (2004), the WC, the HC, and the VC were three distinctly different crustal blocks that amalgamated to form Sri Lanka by two separate plate collisions during the Late Neoproterozoic Gondwana assembly at ca 610-550 Ma following two separate convergent events. This model proposes that the WC may have formed as part of a root zone of a late Mesoproterozoic-Neoproterozoic Andean-type magmatic arc, whereas the VC seems to have originated as part of a Mesoproterozoic island arc (Kehelpannala, 2004). According to this model, the Highland Complex is considered to be a Palaeoproterozoic microcontinent separated from the supercontinent Columbia. The first collision occurred between the WC and the $\mathrm{HC}$ as a result of subduction of the plate containing the $\mathrm{HC}$ microcontinent under the WC magmatic arc (see Fig. 3 of Kehelpannala, 2004). The subsequent subduction of the oceanic plate carrying the $\mathrm{VC}$ island arc under the united WC-HC lithospheric fragment resulted in the second collision, bringing these three units into contact during this second collision (see Fig. 3 of Kehelpannala, 2004). According to this model, granulite facies metamorphisms in both the Wanni and Highland Complexes are related to the first collision, and the high-grade metamorphism of the rocks of the VC is related to the second collision (Kehelpannala, 2014, 2016b). Recently, Kehelpannala (2016b) proposed that the two possible thermal events recorded at about 620-580 Ma and 560-535 Ma based on new LA-ICPMS U-Pb ages of zircons from various lithologies in both the WC and HC (Santosh et al., 2014; Dharmapriya et al., 2016; Osanai et al., 2016a) represent the two separate metamorphic events related to the two-stage plate collisions suggested by Kehelpannala (2003,
2004). Kehelpannala (2016b) further suggested that the first collision may have been responsible for high temperature to UHT granulite-faciesmetamorphism in the HC (e.g. Osanai et al., $2016 \mathrm{~b}$ and references therein), and the second collision probably caused the granulite-facies metamorphism recorded in the $\mathrm{VC}$ prior to its retrogression as is seen today (Kröner et al., 2013).

In contrast, in an attempt to link their Late Neoproterozoic-Cambrian $\mathrm{HC}$ to the metasedimentary terrains in southern India, Santosh et al. (2014) speculated that the HC formed as part of an accretionary complex developed during a $\mathrm{Ne}$ oproterozoic double-sided subduction event involving the Wanni and Vijayan Complexes. This model speculates that HC sediments have deposited as an accretionary complex on a Neoproterozoic ocean between the WC and the VC, and the closure of this ocean by the final collision between these two units during Late Neoproterozoic-Cambrian created the $\mathrm{HC}$ as a suture zone. However, Kehelpannala (2016a), based on Archaean to Paleoproterozoic detrital zircon ages obtained from the HC metasediments (Kröner et al., 1987; Baur et al., 1991; Hölzl et al., 1994; Takamura et al., 2016) and the presence of large volume of Paleoproterozoic metagranitoids in this complex (Kröner et al., 1987; Baur et al., 1991; Hölzl et al., 1994; Santosh et al., 2014), argued that the $\mathrm{HC}$ is an older Palaeoproterozoic unit than the flanking Late Mesoproterozoic-Neoproterozoic WC and the Late Mesoproterozoic $\mathrm{VC}$, ruling out a Neoproterozoic origin for $\mathrm{HC}$ metasediments. Palaeoproterozoic U-Pb detrital zircon ages (Takamura et al., 2016; Kitano et al., 2018) as well as U-Pb zircon crystallization ages of 2061 $\pm 16-1862 \pm 2$ Ma from HC metagranitoids (Kröner et al., 2017, 2018) and the presence of numerous HC metasedimentary enclaves within Palaeoproterozoic metagranitoids (Kehelpannala, 2016a and in preparation) indicate that the $\mathrm{HC}$ is, indeed, an older Palaeoproterozoic unit, and hence rule out the idea of double subduction (Santosh et al., 2014) involved in the origin of the HC (Kehelpannala, 2016a and in preparation; Kröner et al., 2017, 2018). Further, the metasedimentary rocks in the HC represent a passive continental margin sedimentary sequence as 
mentioned earlier, which is inconsistence with the idea that the HC is an accretionary complex as speculated by Santosh et al. (2014) and Takamura et al. (2016).

The two-collision model of Kehelpannala (2004) seems to explain the available data from all the lithotectonic units (see also Touret et al., 2019), including the large volume of HC Paleoproterozoic metagranitoids (Baur et al, 1991; Kröner et al., 2017, 2018), the HC klippen occurring in the south-eastern part of the VC (Fig. 1; Kehelpannala 2016a), the Late NeoproterozoicCambrian metamorphic ages indicating multiple thermal events (Kehelpannala, 2016a and reference therein), and the clockwise P-T paths of the HC and WC (Raase and Schenk, 1994; Osanai et al., 2016b; Dharmapriya et al., 2017a; Touret et al., 2019 and references therein).

\section{DEFORMATION SEQUENCE IN BOTH THE WANNI AND HIGHLAND COMPLEXES}

Both the WC and $\mathrm{HC}$ have undergone polyphase ductile deformation before and during the Gondwana assembly (Berger and Jayasinghe, 1976; Yoshida et al., 1990; Voll and Kleinschrodt, 1991; Kehelpannala, 1991, 1997, 2003; Kriegsman, 1991, 1993, 1994; Kleinschrodt and Voll, 1994; Tani, 2002). Possible pre-Gondwana structures found in the WC have been documented by Kehelpannala (2003). Here we summarize the deformation sequence recognized by Kehelpannala (1997, 2003, 2007b, 2016b). Most visible and well-developed structures in both the WC and HC were formed by the two separate collisions related to Gondwana assembly between $620 \mathrm{Ma}$ and $535 \mathrm{Ma}$ ago (Kehelpannala, 2003, 2004, 2016b). Six phases of ductile deformations $\left(D_{1}\right.$ to $\left.D_{6}\right)$ in the Wanni and Highland Complexes have been recognized (Kehelpannala, 1997, 2003). The first deformation $\left(D_{1}\right)$ in both the WC and $\mathrm{HC}$ occurred during prograde metamorphism (see also Dharmapriya et al., 2017a,b) and is represented by straight to curved and crenulated inclusion trails in garnet porphyroblasts, microfolds in some metapelites and quartzo-feldspathic gneisses and by a $S_{1}$ foliation preserved in crenulation folds and some rootless intrafolial folds. $\mathrm{D}_{2}$ to $\mathrm{D}_{4}$ and granulite facies metamorphism in both the Wanni and Highland Complexes and the UHT metamorphism in the HC were caused by the nearly NNW-SSE collision between these two units (Kehelpannala, 2004, 2016b).

$\mathrm{D}_{2}$ deformation has two main phases. The first phase of $D_{2}$ may have been responsible for the formation of a crenulation cleavage of $\mathrm{S} 1$ as seen in garnet porphyroblasts in some metapelites. The compositional layering $\left(\mathrm{S}_{2}\right)$ in metapelites and metasemipelites have formed through the development of acrenulation cleavage (Kehelpannala, 1997, 2003). The second phase of $D_{2}$ deformation is the most intense and dominant deformation and produced most part of the major composite and transposed compositional layering and related mylonite foliation $\left(\mathrm{S}_{2}\right)$, the prominent stretching lineation $\left(\mathrm{L}_{2}\right)$ and mesoscopic $\mathrm{F}_{2}$ folds in both the WC and HC. $\mathrm{F}_{2}$ folds are mesoscopic, isoclinal, rootless and occur as intrafolial folds, and their limbs are highly attenuated (Kehelpannala, 1997). The axial planes of $F_{2}$ folds are now parallel to the major composite compositional layering $\left(\mathrm{S}_{2}\right)$. Major part of the deformation during the second phase of $\mathrm{D}_{2}$ was non-coaxial and related to the final collision between the $\mathrm{WC}$ and the $\mathrm{HC}$, during which the $\mathrm{WC} / \mathrm{HC}$ boundary shear zone was formed (Kehelpannala, 1997, 2003, 2004, 2016b). Progressive rotation of the F2 fold hinges during $\mathrm{D}_{2}$ non-coaxial flow brought these hinges parallel with $\mathrm{L}_{2}$ stretching lineation in many areas (Kehelpannala, 1997). A detailed description of these prominent foliations $\left(\mathrm{S}_{2}\right)$ and lineations $\left(\mathrm{L}_{2}\right)$ is given in Kehelpannala (2003).

As reported by Kehelpannala (1997, 2003), $\mathrm{D}_{3}$ was responsible for formation of mesoscopic to megascopic recumbent isoclinal folds. A nearly horizontal foliation $\left(\mathrm{S}_{3}\right)$, defined by flattened quartz, has developed in metapelites around Hunnasgiriya and Udadumbara and in charnokitic gneiss around Randenigala in the $\mathrm{HC}$ (Kehelpannala, 2016b). This nearly horizontal foliation $\left(S_{3}\right)$ is related to the $\mathrm{D}_{3}$ deformation, and large-scale isoclinal folds found in the $\mathrm{WC}$ are $\mathrm{F}_{3}$ folds. Hinges as well as axial planes of $F_{2}$ and $F_{3}$ folds in many areas of the $\mathrm{WC}$ and the $\mathrm{HC}$ are 
parallel (e.g. Kehelpannala, 1997, 2003). However, in areas where $F_{2}$ and $F_{3}$ fold hinges are nearly perpendicular to each other, type II interference folds of Ramsay (1967) are sporadically developed (Kehelpannala, 1991, 1997). $\mathrm{D}_{4}$ deformation produced very large and gentle, nearly E$\mathrm{W}$ upright folds and some minor $\mathrm{F}_{4}$ folds, which are found at outcrops around Akurana in the northern part of the Dumbara Synform (Kehelpannala, 2003, 2016b).

The early stage of the nearly E-W collision between the amalgamated $\mathrm{WC} / \mathrm{HC}$ unit and the VC seems to have given rise to $\mathrm{D}_{5}$ deformation which is the second strongest deformation in both the WC and HC (Kehelpannala, 1997, 2003, 2004). $D_{5}$ produced large-scale linear upright folds $\left(\mathrm{F}_{5}\right)$ together with associated as axial plane foliation $\left(\mathrm{S}_{5}\right)$ and parasitic folds $\left(\mathrm{F}_{5}\right)$. The metamorphic conditions during $\mathrm{D}_{5}$ deformation was still granulite facies with temperatures about $100^{\circ}$ $\mathrm{C}$ below the peak metamorphism (Voll and Kleinschrodt, 1991). A nearly vertical foliation defined by quartzo-feldspathic veins or segregations found in the intermediate to mafic rocks in the doubly plunging synforms around Kandy and Mawanella represent $\mathrm{F}_{5}$-axial plane foliations. The superposition of $\mathrm{F}_{5}$-folds on $\mathrm{F}_{4}$-folds formed a pattern of large-scale domes and basins in both the WC and HC (Kehelpannala, 1991, 2003). Refolding of $\mathrm{F}_{5}$ folds in some areas of the $\mathrm{WC} / \mathrm{HC}$ unit was caused by $\mathrm{D}_{6}$, and some crenulation foliations with quartzo-feldspathic veins define the axial plane foliation to these $\mathrm{D}_{6}$ folds (Kehelpannala, 2003).

\section{THE WANNI COMPLEX/HIGHLAND COMPLEX BOUNDARY SHEAR ZONE}

Although the boundary between the Wanni Complex and the Highland Complex (Figs. 1,2) has been studied by many workers (Kehelpannala, 1987, 1991, 1997, 2003; Kriegsmann, 1994; Tani, 2002; Kehelpannala and Ranaweera, 2007; Ranaweera, 2008), its structural and kinematic evolution are yet to be entirely understood. The current WC and the $\mathrm{HC}$ were recognized based mainly on $\mathrm{Nd}$ model ages by Milisenda et al. (1988) who named them as the Western Model
Age Province and the Central Model Age Province, respectively. These units later became the Wanni Complex and the Highland Complex, respectively (Cooray, 1994). Before 1988, the geographical position of the boundary between the western and central geological units of Sri Lanka was not uniform in different publications and was interpreted by various authors as either a lithostratigraphic boundary or a transitional zone (Fernando, 1947; Vitanage, 1959; Cooray, 1961, 1978; Geological Map of Sri Lanka, 1982). On the other hand, Voll and Kleinschrodt (1991) argued, on the basis of their own field observations, that the Wanni and the Highland Complexes probably belong to the same crustal unit, which they named as "the Central Granulite Belt".

Milisenda et al. $(1988,1994)$ were unable to constraint the nature of the boundaries of these model age provinces, although they recognized them as distinct crustal units. However, Kehelpannala (1991) showed that the WC/HC (the former Highland/Southwester Complex) boundary is the contact between the former $\mathrm{KC}$ and the $\mathrm{HC}$ and was able to demarcate its geographical position in the central part of Sri Lanka. Kehelpannala (1991) further argued that the WC and the HC may have come into contact tectonically. Subsequent work by Kehelpannala (1997) confirmed that the $\mathrm{WC} / \mathrm{HC}$, indeed, a crustal-scale ductile shear zone (about 500-1000 m wide), part of which is the Digana shear zone (Kehelpannala, 1987; Voll and Kleinschrodt, 1991). In contrast, Kriegsman $(1993,1994,1995)$ proposed that the WC and the $\mathrm{KC}$ were emplaced northwards as nappes on top of the HC. According to him (Kriegsman, 1993, 1994, 1995), the current $\mathrm{WC} / \mathrm{HC}$ boundary is the contact between his western and eastern Highland Complexes. Although all subsequent work strongly suggests that the $\mathrm{WC} / \mathrm{HC}$ boundary is a deep crustal shear zone (Kehelpannala, 1997, 2003, 2004, 2016b; Tani, 2002; Kroner et al., 2003; Kehelpannala and Ranaweera, 2007; Ranaweera, 2008), so far no detailed study on kinematic analysis has been carried out using associated mesoscopic and microscopic structures. However, its geographical position in the central part of Sri Lanka has accurately been demarcated (Kehelpannala, 1991, 
1997, 2003, 2016b; Kehelpannala and Ranaweera, 2007), and some local structures have been studied in considerable detail (Kehelpannala, 1991, 1997, 2003, 2006, 2016a; Tani, 1999 , 2002; Kreigsman, 1994; Tani and Yoshida, 1996; Kehelpannala and Ranaweera, 2007; Ranaweera, 2008).

Kehelpannala (1997, 2003, 2004), Kehelpannala and Ranaweera (2007) and Ranaweera (2008) demonstrate that the WHBSZ is a suture zone, now exposed as a crustal-scale ductile shear zone that formed under high-temperature (HT) to ultrahigh temperature (UHT) granulite facies conditions during the second phase of $\mathrm{D}_{2}$ non-coaxial deformation related to the final collision between the WC and the HC (Kehelpannala, 2016a). This shear contact is well-established between Habarana and Ginigathhena (Kehelpannala, 2004; Kehelpannala and Ranaweera, 2007; Ranaweera, 2008), and preliminary field investigations in the south-western part of Sri Lanka (Fig. 1), especially between the area west of Ratnapura and Ussangoda, demonstrate that the rocks are highly sheared along the inferred boundary (Kehelpannala and Ranaweera, 2007). A detailed description of the geographical position of the Wanni/Highland Complex boundary shear zone (WHBSZ) in other areas is provided by Kehelpannala (2016a).

In the central and SW part of Sri Lanka, the WHBSZ is folded by $\mathrm{D}_{5}$ large-scale uprights folds (see later), causing it to repeat and reappear in many areas (Fig. 1; Kehelpannala, 1997, 2003, 2016a, b). Recent, U-Pb ages of detrital zircons from metasediments and crystallization ages of metaigneous rocks from both the WC and HC (Kitano et al., 2018) show clear, systematic differences. Zircon ages from the WC are clearly younger than those from the HC (Kitano et al., 2018). These young and old zircon ages are distributed in a zigzag manner across the $\mathrm{WC} / \mathrm{HC}$ boundary confirming the folded nature of the WHBSZ. The compression during $\mathrm{D}_{5}$ deformation (see later) caused the $\mathrm{WC} / \mathrm{HC}$ boundary shear zone to undergo folding forming a complex geometry of the geographical extension of the WHBSZ in the central part of Sri Lanka (Fig. 1) due to the doubly plunging synforms in the above areas (Kehelpannala, 1997, 2003, 2016a). Because of this folding by $\mathrm{D}_{5}$ large-scale uprights fold, the WC/HC boundary shear zone is folded in the areas around Digana, Dumbara, Kandy, Mawanella, Gampola and Nawalapitiya (Fig. 1; see also Fig. 16 of Kehelpannala, 2003). Where the boundary is parallel to the $F_{5}$-fold axes (see Figs. 15 and 18 of Kehelpannala, 2003), the WHBSZ runs parallel to the rock layers as is seen from NW of Trincomalee in NE part of Sri Lanka to the central part, although it is locally folded by F6-folds, especially around Lenadora (Fig. 2). From NW of Trincomalee, the WHBSZ extends towards Digana through Habarana, E of Dambulla, Lenedora, Naula, Nalanda, Palapatwala, E of Matale, Wattegama and Wawinna (Fig. 1; Kehelpannala, 1997, 2016a, b; Kehelpannala and Ranaweera, 2007; Ranaweera, 2008). Where the WHBSZ is oblique to the $\mathrm{F}_{5}$-fold axes, it is folded by these folds (see Figs. 15 and 18 of Kehelpannala, 2003) as is seen in the central part of Sri Lanka from Digana to Ginigathena (Fig. 1) and beyond (Kehelpannala in preparation). Its extension from Ginigathena towards SW is not very clear (Fig. 1) as the $\mathrm{F}_{5}$-folds in this area are very tight (Kehelpannala unpublished data). The folded WHBSZ extends from Digana towards Udapussellawa in the SE through Adikarigama, Malulla, Hakurutale, Walapane, Harasbedda and turns back due to folding by the local $\mathrm{F}_{5}$-fold in the region $\mathrm{W}$ of Udapussellawa (Fig, 1; Kehelpannala, 2016a; see also Fig. 16 of Kehelpannala, 2003). From there the WHBSZ extends north-westwards towards Kandy through Sooriyakanda in the Ragala area, W of Liyanwela, Munwatta, Rikillagaskada, E of Hanguranketa, Kande Handiya, Kivullinda, Mailapitiya and Haragama (see also Kehelpannala, 2016a). Similarly, the WHBSZ runs towards Ginigathhena through SE of Gampola and Nawalapitiya (Fig. 1; Kehelpannala, 2016b). Because of this folding of the $\mathrm{WC} / \mathrm{HC}$ boundary shear zone, any ages derived from rocks in these areas have to be interpreted cautiously (Kehelpannala, 2016a).

Rocks in both the WC and the $\mathrm{HC}$ have been severely sheared by the WHBSZ (Kriegsman, 1994; Kehelpannala, 1997, 2016a,b; Kehelpannala and Ranaweera, 2007; Ranaweera, 2008). 


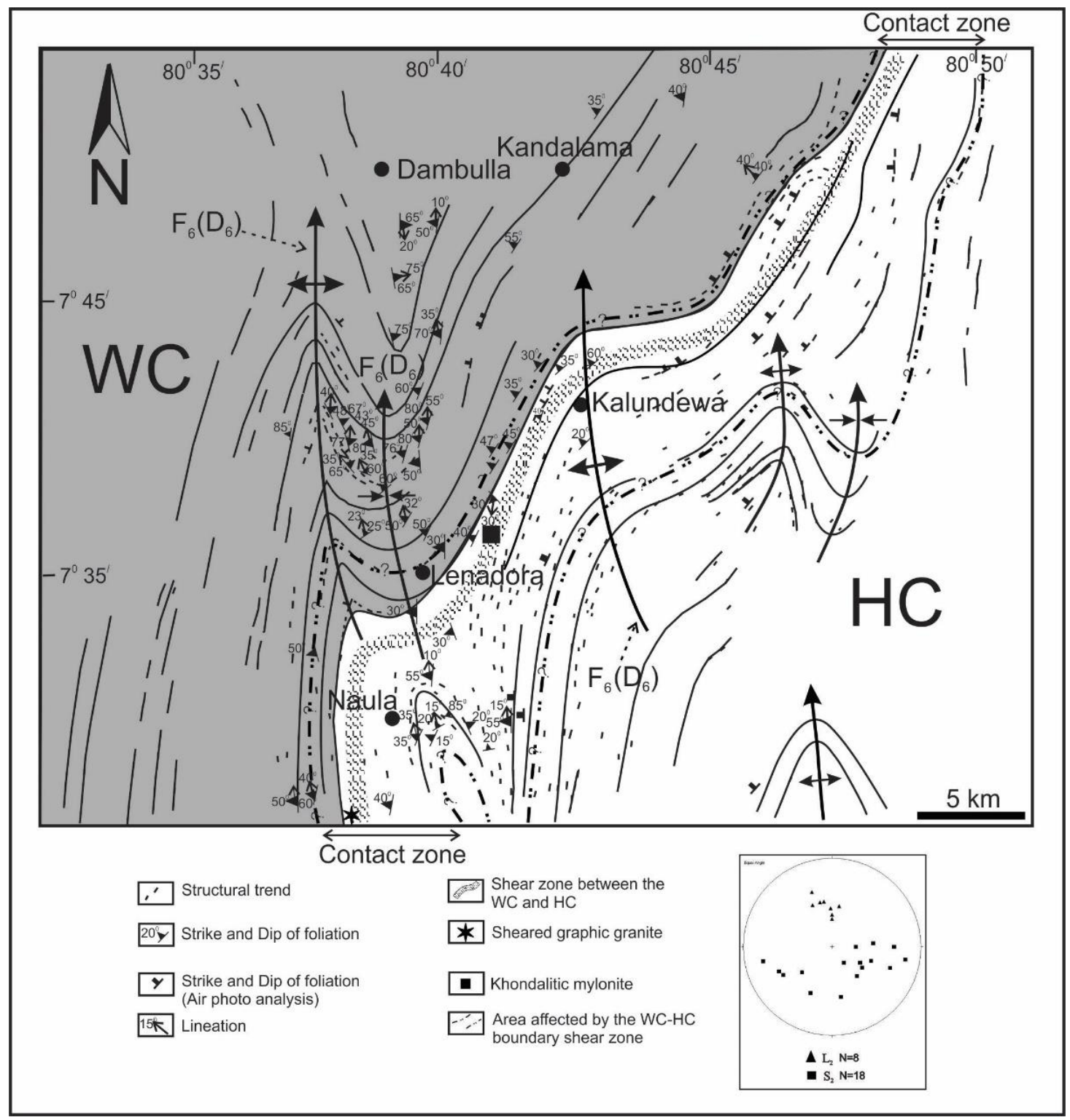

Fig. 2. Structural map along the WC/HC boundary shear zone (WHBSZ) around Naula-LenadoraDambulla area. Stereonet projection shows orientations of the stretching lineation $(\Delta)$ and foliation $(\square)$ around Naula and North of Lenadora. HC-Highland Complex, WC-Wanni Complex. Here the WHBSZ is folded by $F_{6}$ folds. Stretching lineation is oriented in the direction of NNW-SSE.

However, the well-exposed sheared rocks along the major part of the WHBSZ from Ginigathena towards Trincomalee (Fig. 1) belong to the HC and consists of marble, dolomitic marble, calcsilicate gneiss, khondalitic metapelites, metasemipelites and quartzite of sedimentary origin and quartzo-feldspathic orthogneisses. Although some UHT granulites are located along the WHBSZ, it is very important to investigate whether they really belong to the HC. As mentioned earlier, the rocks of the sedimentary origin represent a passive continental margin sedimentary sequence, suggesting that the part of the $\mathrm{HC}$ amalgamated with the WC along the WHBSZ is part of a Palaeoproterozoic continental shelf. Metapelitic gneisses (so-called khondalite) consisting of garnet, sillimanite and graphite and of garnet, sillimanite, spinel and graphite, metasemipelitic rocks with garnet and biotite, marble layers, calc-silicate rocks and metagranitoids are all interlayered. This field relationship clearly indicates that these Palaeoproterozoic granitoids have intruded into an already existing sedimentary package in the $\mathrm{HC}$ and that the $\mathrm{HC}$ precursor sediments were deposited during Palaeoproterozoic as mentioned earlier (Kehelpannala, 
2016a and in preparation). The Digana and Victoria granitoids make major part of the above quartzo-feldspathic ortho-gneisses (metagranitoids), and U-Pb zircon ages from these rocks indicate that they have intruded the above-mentioned continental shelf type sediments during Palaeoproterozoic (Baur et al, 1991;Kehelpannala, 2016a; Kröner et al., 2017; 2018). A key feature of the WHBSZ is that the rock succession containing both the above metasediments and orthogneisses maintains more or less the same structural level along its entire length. All the above rocks are strongly mylonitized by the WHBSZ, and for the detailed study of mesoscopic and microscopic structures and for kinematic analysis, pelitic mylonites and quartzofeldspathic mylonites (striped gneiss) from several localities along the WHBSZ (Fig. 1) were selected.

\section{TYPES OF MYLONITES FORMED ALONG THE WHBSZ}

In this study we investigated a long stretch of the WHBSZ from Habarana to Ginigathena (Fig. 1). It was observed that all the rocks along this entire stretch of the boundary shear zone are severely mylonitized forming different types of mylonites. The sheared rocks observed indicate that the shear zone is about $1000 \mathrm{~m}$ wide in most areas (see also Kehelpannala, 1991, 1997, 2003; Voll and Kleinschrodt, 1991), and in some areas the zone affected by shearing could even be up to about 4-5 km (Fig. 2). Early work on this shear zones indicate that shearing along the WHBSZ is mainly simple shear or non-coaxial (Kehelpannala, 1991, 1997, 2003; Kriegsman, 1993, 1994: Kehelpannala and Ranaweera, 2007). In this study we selected the following types of major mylonites along the above stretch of the WHBSZ for the detailed analysis of mesoscopic and microscopic structures and for understanding shear sense indicators associated with the shear zone.

1. Pelitic mylonites or khondalitic mylonites

2. Semipelitic mylonites

3. Quartzo-feldspathic mylonite (striped gneiss)

\section{PELITIC MYLONITES (KHONDALITIC MYLONITES)}

Along the Wanni Complex/Highland Complex boundary shear zone, two major types of pelitic or khondalitic mylonites (Figs. 3-5) are found. These are (i) garnet-sillimanite-alkali feldspar-quartz-graphite gneiss, known as khondalite (e.g. Katz, 1971; Hiroi et al., 1994, 1997) and (ii) spinel (hercynite)-plagioclase-sillimanite-garnetalkali feldspar-quartz-graphite gneiss. This latter rock type has been named as "unusual khondalite" by Hiroi et al. (1997). Both these pelitic rock types, known as khondalite, have been recognized by Kehelpannala and Ranaweera (2007) as mylonite (Figs. 3-5), and their characteristic structural features and mineralogy are described below. For easy distinction, here we name the first type of khondalite as the "normal khondalitic mylonite" (Figs. 3a,c,e, 4a,c,e,) and the second type as "spinel-bearing khondalitic mylonite" (Figs. 3b,d,f, 4b,d,f).

\section{(i) Normal khondalitic mylonite and their mesoscopic to microscopic structures}

This normal khondalitic mylonite (typical khondalite) contains large garnet porphyroblasts, sillimanite, alkali feldspar, quartz and graphite (Figs. 3a,c,e, 4a,c,e,). About several metres thick, two or more khondalitic mylonite layers, interlayered with thick marble bands, occur along the entire length of the WC/HC boundary from around Gingathena towards Trincomalee through Nawalapitiya, Paradeka, Gampola, Peradeniya, Kandy, Ampitiya, Haragama, Diagana, Wattegama, E of Matale, North Matale (North of Palapatwala), Nalanda, Naula, Lenadora and Habarana. Wherever the WHBSZ is repeated due to folding by $\mathrm{F}_{5}-$ folds, these rocks are found. In addition to the above khondalitic mylonite layers, large boudins or detached bands of khondalitic mylonite occur within the above marble bands. The second type of khondalitic mylonite (spinel-bearing khondalitic mylonite) also occurs along the WHBSZ closely associated with the normal khondalitic mylonite. For detailed structural and mineralogical analysis, we selected khondalitic mylonites from three different localities (Fig. 1), namely 

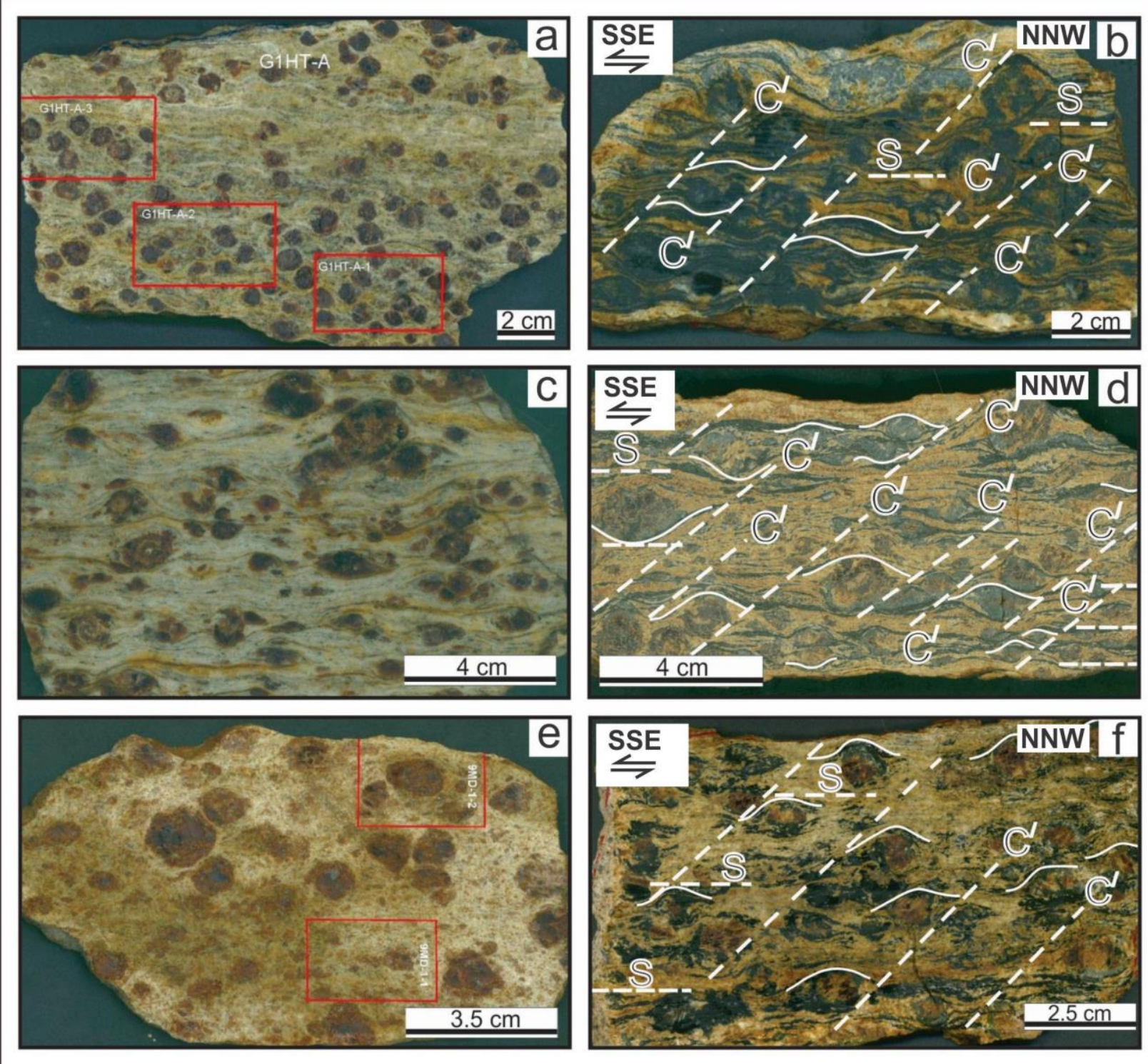

Fig. 3. Field photographs showing khondalitic mylonites found at Habarana, Lenadora and Palapatwala. (a) Normal khondalitic mylonite with garnet, sillimanite and graphite from Habarana. (b) Spinel-bearing khondalitic mylonite from Habarana. Most of the garnet porphyroblasts have been replaced by spinelplagioclase symplectite. Note $S$-C'fabrics with $C^{\prime}$-type shear bands dipping to the left and the blastomylonitic texture with peacock-feather appearance. (c) Normal khondalitic mylonite from Lenadora. (d) Spinelbearing khondalitic mylonite from Lenadora. Note clearly visible $S$-C'fabrics with $C^{\prime}$-type shear bands dipping to the left. (e) Normal khondalitic mylonite from Palapatwala. (f) Spinel-bearing khondalitic mylonite with $S$-C'fabric found at Palapatwala. $C^{\prime}$-type shear bands dip to the left. These nearly vertical SSE$N N W$ views show a top-to-the SSE movement.

Habarana (Figs. 3a, 4a), Lenadora (Figs. 3c, 4c) and Palapatwala (Figs. 3e, 4e). Petrological, mineralogical and chemical analyses of this type of pelitic rocks from other parts of Sri Lanka, including some along the WHBSZ, have been studied by many workers (Hiroi et al., 1994, 1997; Raase and Schenk, 1994; Osanai et al., 2006, 2016b; Dharmapriya et al., 2015, 2016, 2017a,b and references therein). Although these khondalitic layers occur as thick, distinct bands, sampling from these rocks was not possible as they are highly weathered. Therefore, fresh khondalitic mylonite samples studied here were collected from boudinaged mylonitic layers or blocks preserved within marble at all the three localities (Figs. 1, 3a,c,e, 4a,c,e). 

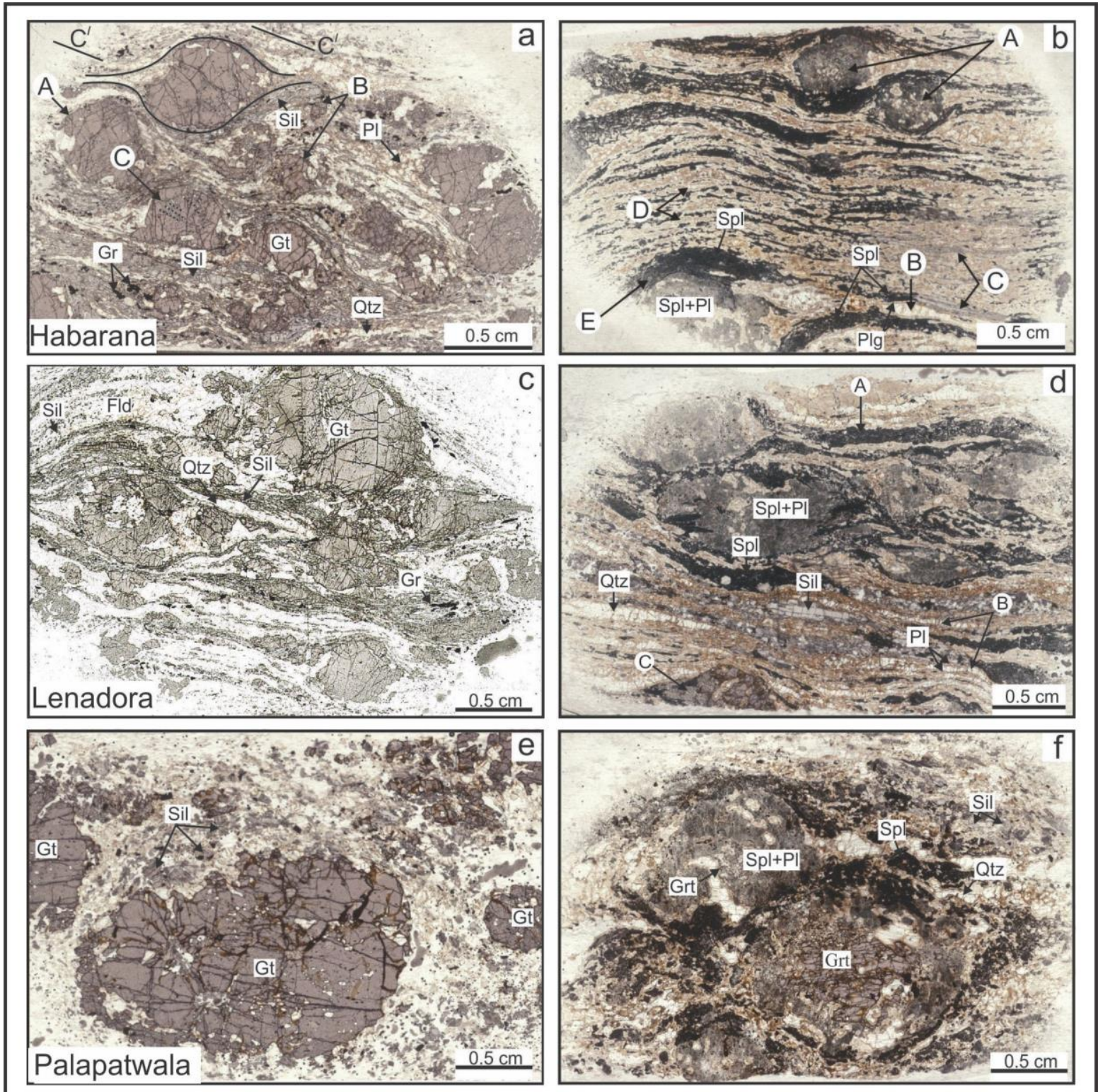

Fig. 4. Scanned thin sections showing mineral assemblages in khondalitic mylonite. (a) Normal khondalitic mylonite at Habarana. (b) Spinel-bearing khondalitic mylonite at Habarana. Note garnet pseudomorphs (A), plagioclase and quartz in pressure shadows around the garnet pseudomorphs, stretched quartz grains $(B)$, oriented sillimanite in the mylonitic matrix $(C)$, quartz mantled by plagioclase $(D)$ and spinel-plagioclase (E). (c) Normal khondalitic mylonite at Lenadora. (d) Spinel-bearing khondalitic mylonite at Lenadora. Note garnet pseudomorphs, spinel replacing matrix sillimanite (A) and the stretched quartz grains $(B)$ in the matrix. (e) Normal khondalitic mylonitic at Palapatwala. (f) Spinel-bearing khondalitic mylonite at Palapatwala. Note partial replacement of garnet by spinel-plagioclase symplectite. Normal khondalitic mylonite at all Habarana, Lenadora and Palapatwala show similar metamorphic evolution.

Mineralogically, the normal khondalitic mylonite contain garnet porphyroclasts, sillimanite, quartz, K-feldspar (usually perthite to mesoperthite) and graphite, and ilmenite, apatite, monazite, pyrite and zircon occur as accessory minerals (see also Hiroi et al., 1994, 1997). Garnet-sillimanite-quartz-K-feldspar-graphite in these mylonites represents the peak metamorphic assemblage (Fig. 4a, c, e). A very important feature of the normal khondalitic mylonites studied is the lack of biotite (Figs. 3a,c,e, 4a,c,e), indicating that these mylonites have formed under very dry conditions or under low $\mathrm{H}_{2} \mathrm{O}$ fugacity (Hiroi et al., 1997). Even if biotite is present, it is a very 
minor phase in the khondalitic mylonites at all the three localities studied, and it occurs as a rare matrix mineral as well as an inclusion in garnet. Perhaps biotite was present in the prograde metamorphic stage and might have been completely consumed by garnet growth reactions (e.g. Hiroi et al. 1994; Raase and Schenk, 1994; Dharmapriya et al, 2017b). Graphite present is usually associated with sillimanite in the matrix (Fig. 4a,c). Graphite apparently is not in contact with garnet but may occur as inclusions in garnet. The above mineral assemblages are products of the major HT granulite facies metamorphism of the HC rocks (e.g. Hiroi et al. 1994; Raase and Schenk, 1994; Osanai et al., 2006, Dharmapriya et al, 2017b).

Garnet porphyroblasts in these khondalitic mylonites is very large and vary in grain size from about $1 \mathrm{~mm}$ to over $2 \mathrm{~cm}$ (Figs. 3a,c,e), and at some outcrops, the average size is larger than 2 $\mathrm{cm}$. At Habarana, the garnet porphyroblasts in the normal khondalitic mylonites are mostly rounded and have nearly the same size (Fig. 3a). Their average size is about $8-10 \mathrm{~mm}$ with a few grains having a size smaller than the average (Fig. 3a). Although mineral inclusions in garnet porphyroblasts in the mylonite at Habarana are common, only a few of them show internal fabrics indicating rotation of the garnet (see upper left corner of Fig. 3a). In contrast, garnet porphyroblasts in normal khondalitic mylonite collected from boulders within a marble at the base of a big dug well at Lenadora (Figs. 1, 2, 3c) are elongated and show variable grain sizes with the majority of them having large size (11-24 mm). At this locality, the above marble having khondalitic mylonite boudins is sandwiched between an upper garnet-biotite-gneiss layer and a lower quartzo-feldspathic gneiss band (mylonite). Garnet porphyroblasts in the normal khondalitic mylonite at Lenadora show clear evidence of garnet rotation (Figs. 3c, $5 \mathrm{c}, \mathrm{d})$. The normal khondalitic mylonite collected at Palapatwala (Figs. 1, 3e) was from boulders in a disturbed outcrop of highly weathered metapelite. The surrounding rock of the normal khondalitic mylonite at this locality is garnet-biotite-gneiss, which overlies a thick marble layer. Garnet porphyroblasts in the Palapatwala normal khondalitic mylonite vary in size from $\sim 0.8 \mathrm{~mm}$ to $18 \mathrm{~mm}$, and the majority of garnet grains are medium- to coarse-grained (Fig. 3e). The above three mylonite bodies, which are spatially several kilometres apart, have similar mineralogical and textural features (Fig. 3a, c, e) and the same composition, indicating that these represent a once continuous khondalitic mylonite layer along the WHBSZ.

In all these normal khondalitic mylonites from all the localities, sillimanite is a major mineral formed during HT granulite facies metamorphism and occurs in the foliation plane (mylonitic foliation - XY plane of the finite strain ellipsoid) with its c-axis is parallel to the stretching lineation. In sections or views parallel to the $\mathrm{XZ}$ plane (parallel to the stretching lineation and perpendicular to the foliation) of the finite strain ellipsoid, c-axis of sillimanite and hence its prismatic planes are parallel to the stretching lineation (Figs. 3a,c,e, 4a,c), and in sections or views parallel to the $\mathrm{YZ}$ plane (perpendicular to both the stretching lineation and foliation), basal planes of sillimanite are visible. In all these normal khondalitic mylonites, sillimanite anastomose around garnet porphyroblasts (Figs. 3a,c,e, 4a,c, 5a-d) (see also Kehelpannala, 1997).

Usually, sillimanite grains in these khondalitic mylonites are very long, sometimes up to about $2 \mathrm{~cm}$ or more, and parallel to the stretching lineation, and on views perpendicular to the lineation, grain size is smaller. For example, at Lenadora, sillimanite in the matrix viewed perpendicular to the stretching lineation varies from very fine $(0.05-0.3 \mathrm{~mm})$ to medium $(3-5 \mathrm{~mm})$ in size. Here sillimanite is associated with $\mathrm{K}$-feldspar and graphite, and sometimes, it occurs as thin small layers (Figs. 3c, 4c). Graphite in these khondalitic mylonites is found in the matrix as well as in garnet porphyroblasts as inclusions. In all the cases, some garnet porphyroblasts contains sillimanite inclusions. The matrix sillimanite grains $(-1 \mathrm{~mm}$ to over $2 \mathrm{~cm}$ ) in thin sections cut parallel to the $\mathrm{XZ}$ plane of the finite strain ellipsoid are over 50 - 200 times larger than the sillimanite inclusions $(<10 \mathrm{~mm}-100 \mathrm{~mm})$ in garnet, indicating that the two sillimanite types belong to two different generations (see also Kehelpannala, 1997). In the 
Habarana khondalitic mylonite, the size of graphite varies from $0.15 \mathrm{~mm}-1.5 \mathrm{~mm}$, whereas graphite in the Lenadora mylonite ranges from 0.05-1 $\mathrm{mm}$.

At mesoscopic-scale, all the normal khondalitic mylonites studied from Habarana, Lenadora and Palapatwala show rotated garnet porphyroblasts (Figs. 3a,c,e). Some of these garnets contain rotated inclusion trails, and some of them are even spiral garnet with double spiral inclusions (Figs. 3c, 5c,d), which have grown syntectonically. These rotated inclusion trails and double spiral inclusions clearly indicate that the sense of shear along the WHBSZ is from NNW to SSE. In addition, careful observation of these normal khondalitic mylonites demonstrates that they have developed $\mathrm{C}^{\prime}$-type shear band foliations (Fig. 3a,c,e, 4a, 5a,b), which indicate the movement along the WHBSZ from NNW to SSE. In rare cases, for example, in the normal khondalitic mylonite at Habarana, microscopic-scale, domino-type fragmented porphyroclasts (e.g. Passchier and Trouw, 2005) of garnet are found (Fig. 5f). The sense of shear deduced from these antithetic microfaults in domino-type fragmented garnet porphyroclasts (Fig. 5f) is consistent with the motion on the WHBSZ (Figs. 3a,c,e, 4a,c,e, 5a-d). The rotated and spiral garnets, $C^{\prime}$-type shear band foliations and other shear sense indicators in the normal khondalites along the WHBSZ indicate that these rocks have formed as mylonites and that the movement along the shear zone is from NNW to SSE (top-to-the-SSE).

\section{Growth of garnet porphyroblasts in khondalitic mylonites}

Mineral reactions leading to the formation of garnet porphyroblasts in Sri Lankan khondalite have been studied by many workers (e.g. Schumacher et al., 1990; Raith et al., 1991; Kriegsman, 1991; Raase and Schenk, 1994; Hiroi et al., 1994, Osani, 2006, 2016b; Dharmapriya et al., 2017b and references therein), and mechanisms of growth of garnet in these rocks have been proposed by Kehelpannala (1997, 2016a) and Dharmapriya et al. (2017b). In all the above studies, the formation of garnet has related to dehydration reactions at high temperature to UHT granulite facies metamorphic conditions (see Dharmapriya et al., 2017b and references therein). Inclusions of sillimanite, ilmenite, kyanite and andalusite, quartz, feldspar, biotite, graphite, rutile, zircon and other heavy minerals, most having a preferred orientation within their hosts, have been found in garnet porphyroblasts in metapelites from many parts of Sri Lanka (Hiroi et al., 1987; Yoshida et al., 1990; Kehelpannala, 1991, 1997, 2003; Schenk et al., 1991; Kriegsman, 1991; Osanai et al., 2006, 2016b; Dharmapriya et al., 2017b). Most of these inclusion trails are found at the cores of garnets, whose rims are nearly free of inclusions, suggesting that the garnet cores were old and were overgrown during a later event (Kehelpannala, 1997). As mentioned earlier, these straight to curved and crenulated inclusion trails in garnet porphyroblasts in metapelites, including the khondalitic mylonites, and metasemipelites represent microstructures related to the first deformation and are overgrown by garnet cores during the early stages of $\mathrm{D}_{2}$ (Kehelpannala, 1997). The inclusions free garnet rims may be related to the late phase of $\mathrm{D}_{2}$, which was probably coeval with the peak conditions of high temeparture to UHT granulite facies metamorphism (Kehelpannala, 1997; Dharmapriya, 2017). The growth of some garnets during early $\mathrm{D}_{2}$ may also be supported by the presence of stretching shadows, parallel to the prominent stretching lineation $\left(\mathrm{L}_{2}\right)$ around garnets in some metapelites from Sri Lanka (Kehelpannala, 1997).

Studies carried out by Kehelpannala and Ranaweera (2007), Ranaweera (2008) and Kehelpannala (2016a) indicate that khondalites (garnet-sillimanite-alkali feldspar-quartz-graphite gneisses) and spinel-bearing khondalite exposed along the WHBSZ have formed as mylonites during the initial stages of mylonitization along this shear zone. Recently, Kehelpannala (2016a) suggested that these pelitic mylonites and other metapelites (so-called khondalite) have developed $\mathrm{C}^{\prime}$-type shear band foliations during shear along the WHBSZ, and within the low strain zones between $\mathrm{C}^{\prime}$-type shear bands and S-planes, garnet porphyroblasts have grown (Kehelpannala, and in 


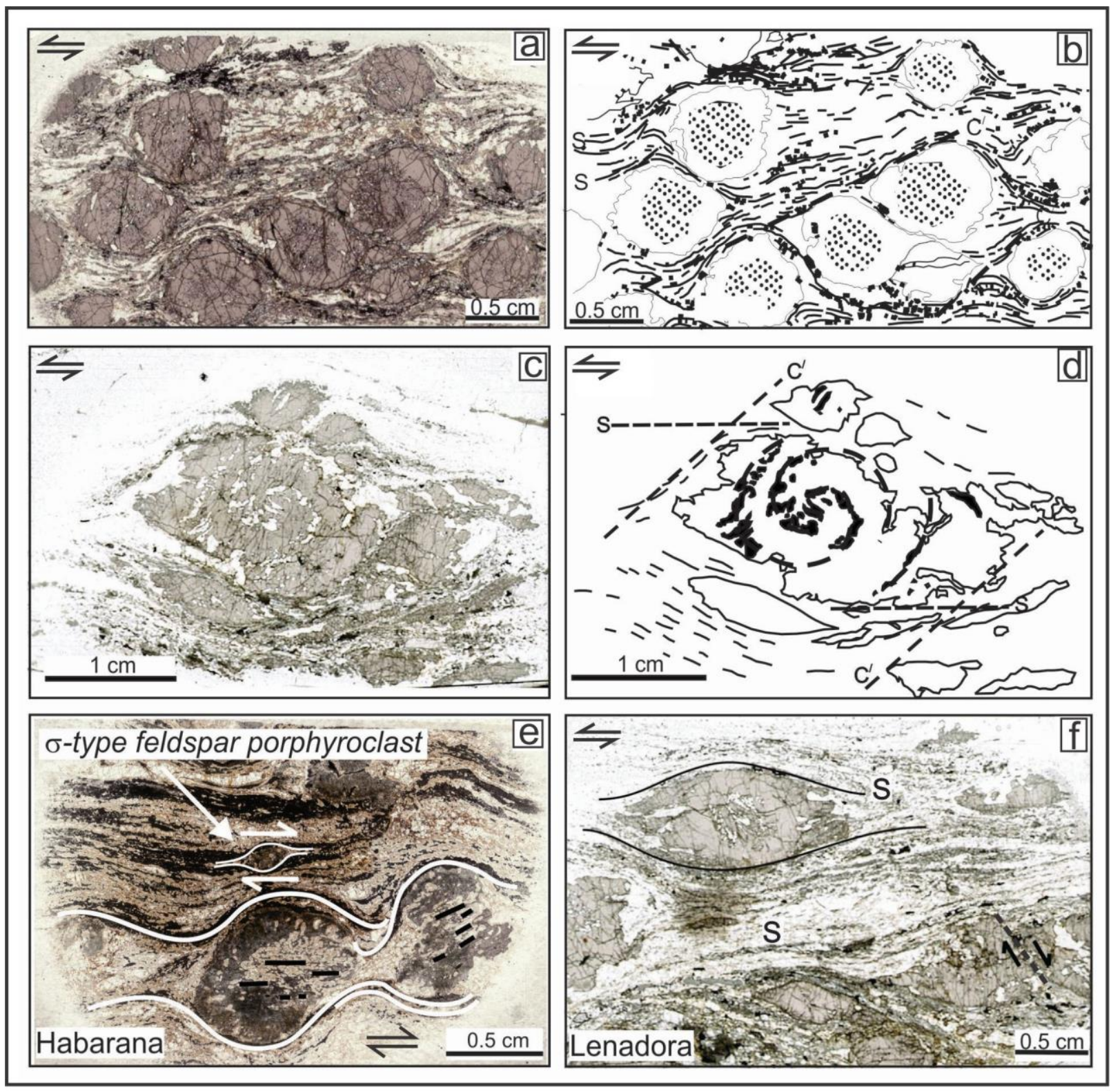

Fig. 5. Shear sense indicators in mylonites along the WHBSZ. (a) Scanned thin sections showing $S$ - $C^{\prime}$ fabrics in the Habarana normal khondalitic mylonite. (b) Line drawing of a. Thin lines - sillimanite. Spinel is black. Inclusions in garnet are shown with dots. (c) Scanned thin sections showing a spiral garnet with double spiral inclusions from the Lenadora normal khondalitic mylonite. External foliation with sillimanite wraps around garnet. Black is graphite. (d) Line drawing of $c$. Thin lines - sillimanite. (e) Scanned thin sections showing asymmetric feldspar porphyroclast in the Habarana spinel-bearing khondalitic mylonite. Note rotated matrix foliation. (f) Scanned thin sections showing high-grade domino-type fragmented garnet (lower right corner). All these examples show an overall sense of movement from NNW to SSE (top-to-the SSE).

preparation). This indicates that local shearing along these incipient $\mathrm{C}^{\prime}$-type shear bands and $\mathrm{S}$ planes causes dissolution releasing elements for growth of garnet at low strain zones between them (Kehelpannala, 2016a and in preparation). Such shear-strain controlled dissolution is very common in metamorphic rocks (e.g. Gray, 1979; Bell and Johnson, 1992). By this way, garnet porphyroblasts up to about $2-4 \mathrm{~cm}$ can grow in pelitic rocks producing metapelitic mylonites, known as khondalite, due to dehydration reactions during granulite facies to UHT metamorphism (Kehelpannala, in preparation). Some asymmetrically crenulated inclusion trails in many garnet porphyroblasts (e.g. Kehelpannala, 1997) and $C^{\prime}$-type shear bands foliations found in 
khondalitic mylonites along the WHBSZ support this idea. Similar metapelitic mylonite with garnet grown wthin low strain zones between $\mathrm{C}^{\prime}$ type shear bands and S-planes are exposed at many localities along the Randenigala road (Kehelpannala, 2016a). Continuous shear along the WHBSZ can cause further local shearing along $C^{\prime}$-type shear bands foliations even after the growth of garnet porphyroblasts, causing dissolution at garnet rims. As this kind of dissolution causes removal of silica (e.g. Gray, 1979) along these discrete $\mathrm{C}^{\prime}$-type shear bands foliations, zoned garnet porphyroblasts with variable composition, especially with respect to silica, can form (Kehelpannala in preparation). In this way, garnet porphyroblasts with silica-saturated cores and silica-deficient rims may form in these mylonites (Kehelpannala in preparation). Subsequence growth of garnet after the cessation of shearing may form garnet porphyroblasts with silica-saturated cores, silica-deficient mantle and silica-saturated rims (Kehelpannala in preparation). In addition, garnet porphyroblasts can overgrow $\mathrm{C}^{\prime}$ type shear bands foliations after the cessation of the shearing producing garnet with silica-deficient cores and silica-saturated rims (Kehelpannala in preparation).

Recently, Dharmapriya et al. (2017b) studied garnet porphyroblasts from UHT metapelite in the HC, probably collected along the WHBSZ, and reported that garnet porphyroblasts formed via dehydration reactions have cores grown at silica-saturated microdomains and mantle to rim areas grown at silica-deficient microdomains. They also found some other garnets formed via dehydration reactions in the same rock with cores grown at silica-deficient microdomains while mantle to rim areas grown at silica-saturated microdomains. They (Dharmapriya et al., 2017b) attributed these different growths of garnet cores and rims to different effective bulk compositional microdomains during the prograde evolution of the HC. They concluded that these microdomains could represent heterogeneous compositional layers, namely palaeobedding or laminations, in the precursor sediments or differentiated crenulation cleavages that existed during prograde metamorphism (Dharmapriya et al., 2017b). However, these different growths of garnet cores and rims with variable silica saturation may be due to the fact that these garnet porphyroblasts have grown in pelitic mylonites with $\mathrm{C}^{\prime}$-type shear bands foliations associated with the WHBSZ as mentioned above (Kehelpannala in preparation).

\section{(ii) Spinel-bearing khondalitic mylonite and their mesoscopic to microscopic strutures}

The spinel-bearing khondalite contains spinel, garnet, K-feldspar, plagioclase and sillimanite, which have undergone mylonitization. The spinel is mainly hercynite (see Hiroi et al., 1997). We (Kehelpannala and Ranaweera, 2007; Ranaweera, 2008) found this spinel-bearing khondalitic mylonite intimately associated with the normal khondalitic mylonite described above at many places, especially at Habarana, Lenadora, North Matale, Palapatwala, around Kivullinda and Nawalapitiya, along the WHBSZ occupying nearly the same structural level. The fabrics of these spinel-bearing khondalite mylonites are very similar to those of the normal khondalitic mylonites (Fig. 3). This type of khondalite was first reported from Habarana by Hiroi et al. (1997), which they named as unusual khondalite. It is possible that this rock type should be found in other areas along the WHBSZ. Recently, Dharmapriya et al. (personal communication) found similar spinel-bearing khondalite along the WHBSZ at a locality NE of Matale.

We studied spinel-bearing khondalitic mylonite from Habarana, Lenadora, Palapatwala and Nawalapitya (Figs. 3b,d,f, 4b,d,f, 6), which are closely associated with the normal khondalitic mylonites (Figs. 3a,c,e) that were described earlier. At mesoscopic-scale, the spinel-bearing mylonite from Habarana, Lenadora and Palapatwala show well-developed $\mathrm{C}^{\prime}$-type shear bands foliations as well as rotated garnet porphyroblasts (Figs. 3b,d,f, 6f). Sillimanite has grown along both the C'-type shear bands and S-planes (mylonitic foliation) and anastomoses around garnet porphyroblasts (Figs. 3b,d,f). It is clear that garnet porphyroblasts in these spinel-bearing khondalitic mylonites have grown in low strain zones between $\mathrm{C}^{\prime}$-type shear bands and S-planes 
(Figs. 3b,d,f) as explained earlier. Microscopicscale $\sigma$-type asymmetric feldspar porphyroclasts observed in spinel-bearing khondalitic mylonite at Habarana (Fig. 5f) along the WHBSZ indicates a movement along the shear zone from top-to-the SSE. The remarkable difference between the normal and spinel-bearing khondalitic mylonites is the formation of spinel-plagioclase symplectites in the latter (Fig. 6).

Before the formation spinel-plagioclase symplectites, the texture, growth mechanisms, size, shape and distribution of garnet and sillimanite of these spinel-bearing khondalitic mylonites were very similar to those of the normal khondalitic mylonites (compare Figs. 3a,c,e with Figs. 3b,d,f). Some of the garnet porphyroblasts in these spinel-bearing khondalitic mylonites contain very fine to medium $(0.1-0.5 \mathrm{~mm}$ to $1-1.5$ $\mathrm{mm}$ ) quartz and plagioclase (Fig. 7a) as well as very fine biotite inclusions, one with a shape of a micro mica fish (Fig. 7g) and the other having kink bands (Fig. 7h). Rims of some of these garnet grains contain randomly oriented fibrous sillimanite inclusions. The above biotite inclusions and fibrous sillimanite in the rims of garnet indicate that the rims have grown after the major shearing event.

Mesoscopic and microscopic observation demonstrate that the spinel-bearing khondalitic mylonites from Habarana, Lenadora and Palapatwala have formed from the normal khondalitic mylonite through the development of spinel-plagioclase symplectites replacing sillimanite and garnet (Figs. 3, 4; Hiroi et al., 1997) with different degree of replacement after the HT granulite facies to UHT metamorphism replacing both matrix sillimanite and garnet (Figs. 3b,d,f, 4b,d,f, 5e, 6). Two major types of spinel-plagioclase associations were found in these khondalitic mylonites, although Hiroi et al. (1997) reported three occurrences. These two types are spinel-plagioclase symplectites replacing (a) matrix sillimanite and (b) garnet porphyroblasts (Figs. 3b,d,f, 4b,d,f, 5e, 6). In these spinel-bearing khondalitic mylonites, quartz does not co-exist with spinel as both minerals are separated by a thin film of feldspar (Fig. 6a), a feature observed not only in this type of rocks but also in normal khondalite (see also
Hiroi et al., 1997).

The matrix sillimanite is partially or completely replaced by spinel-plagioclase symplectites, which have mimetically grown preserving the mylonite foliation of the rocks (Figs. 3b,d,f, 4b,d,f, 5e, 6). Garnet porphyroblasts in these rocks have also been, partially or completely, replaced by spinel-plagioclase symplectites (Figs. 3b.d.f, 4b,d,f, 5e, 6). Completely replaced garnets porphyroblasts are now seen as pseudomorphs of spinel-plagioclase symplectites (Figs. 4b,d,f, 5e, $6)$. It is interesting to note that spinel-plagioclase symplectites replacing garnet porphyroblasts mimic the shape of the pre-replaced garnet (Figs. 3b.d.f, 4b,d,f, 5e, 6). The spinel produced by replacing sillimanite is more darker in appearance than the spinel symplectite replacing garnet.

The Nawalapitiya spinel-bearing pelitic mylonite (Fig. 8) occurs about $5 \mathrm{~km} \mathrm{SE}$ of the town in the Greenwood Estate (Fig. 1). This mylonite, which is interlayered with mylonitized charnockite, is highly sheared having strongly developed mylonitic foliation and stretching lineation (Fig. 8). Here the stretching lineation in the pelitic rock is defined by stretched quartz, elongated aggregate of recrystallized feldspar and c-axes of sillimanite needles. The mineral present in this mylonite are garnet, sillimanite, spinel, quartz, Kfeldspar, plagioclase, graphite and pyrite. The spinel-bearing metapelitic mylonite has two types of layers; one containing spinel and the other without spinel (Figs. 8a,b). Similar to the spinelbearing mylonites at Habarana, Lenadora and $\mathrm{Pa}-$ lapatwala, spinel in this mylonite occurs in two modes; one in spinel-plagioclase symplectite replacing garnet and the other in the matrix parallel to the mylonitic foliation replacing sillimanite. The mineral assemblage of the spinel-free layers is quartz, plagioclase, $\mathrm{K}$-feldspar, garnet and sillimanite and that of the spinel-bearing layers is spinel, plagioclase, K-feldspar, garnet, quartz and sillimanite. The mineralogy and the mineral textures are nearly similar to those found in the khondalitic mylonites found at Habarana, Lenadora and Palapatwala. However, the main difference between this spinel-bearing mylonite and those of the above localities is the lack of S-C or $\mathrm{S}-\mathrm{C}^{\prime}$ fabric in the former. This difference may be 

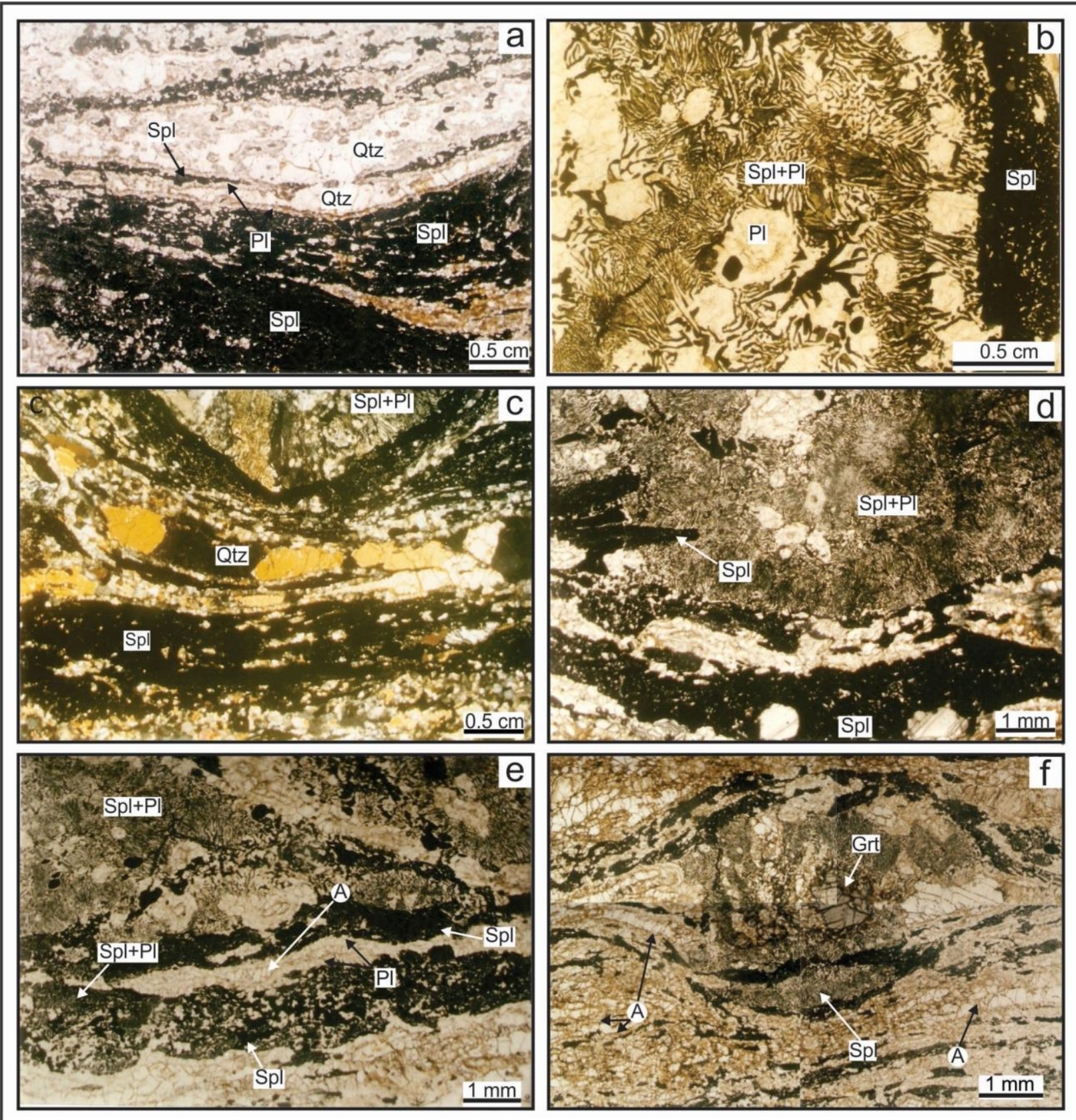

Fig. 6. Photomicrographs showing spinel-bearing khondalitic mylonites. (a) Spinel-plagioclase symplectite in the matrix (lower part of the photo). Note stretched quartz is surrounded by a thin film of feldspar. (b) Spinel-plagioclase symplectites (light coloured) replacing garnet. Note dark spinel-plagioclase symplectite replacing matrix sillimanite near the right edge of the photograph. (c) Spinel-plagioclase symplectites (light coloured) completely replacing garnet surrounded by dark spinel-plagioclase symplectite replacing matric sillimanite. Note stretched quartz grains surrounded by dynamically recrystallized fine-grained aggregates of plagioclase (centre of the photograph). (d) Dark spinel-plagioclase symplectites replacing matrix sillimanite and light-coloured symplectite replacing garnet (Lenadora). Note inclusions within the garnet pseudomorph (upper part of the photograph). (e) Dark spinel-plagioclase symplectite replacing matrix sillimanite encircling quartz rimmed by feldspar. Note quartz and spinel do not coexist. (f) Photomicrographic mosaic of a rotated garnet replaced by spinel-plagioclase symplectite in the Palapatwala mylonite. Note rotated inclusion trails in garnet, and dark spinel replacing matrix sillimanite encircles the outline of the garnet. Note also stretched quartz in the matrix (A). Sillimanite needles, stretched quartz and dynamically recrystallized plagioclase in all examples are related to the shearing along the WHBSZ, and spinel-plagioclase symplectites are caused by post-shearing fluids (see the text). 

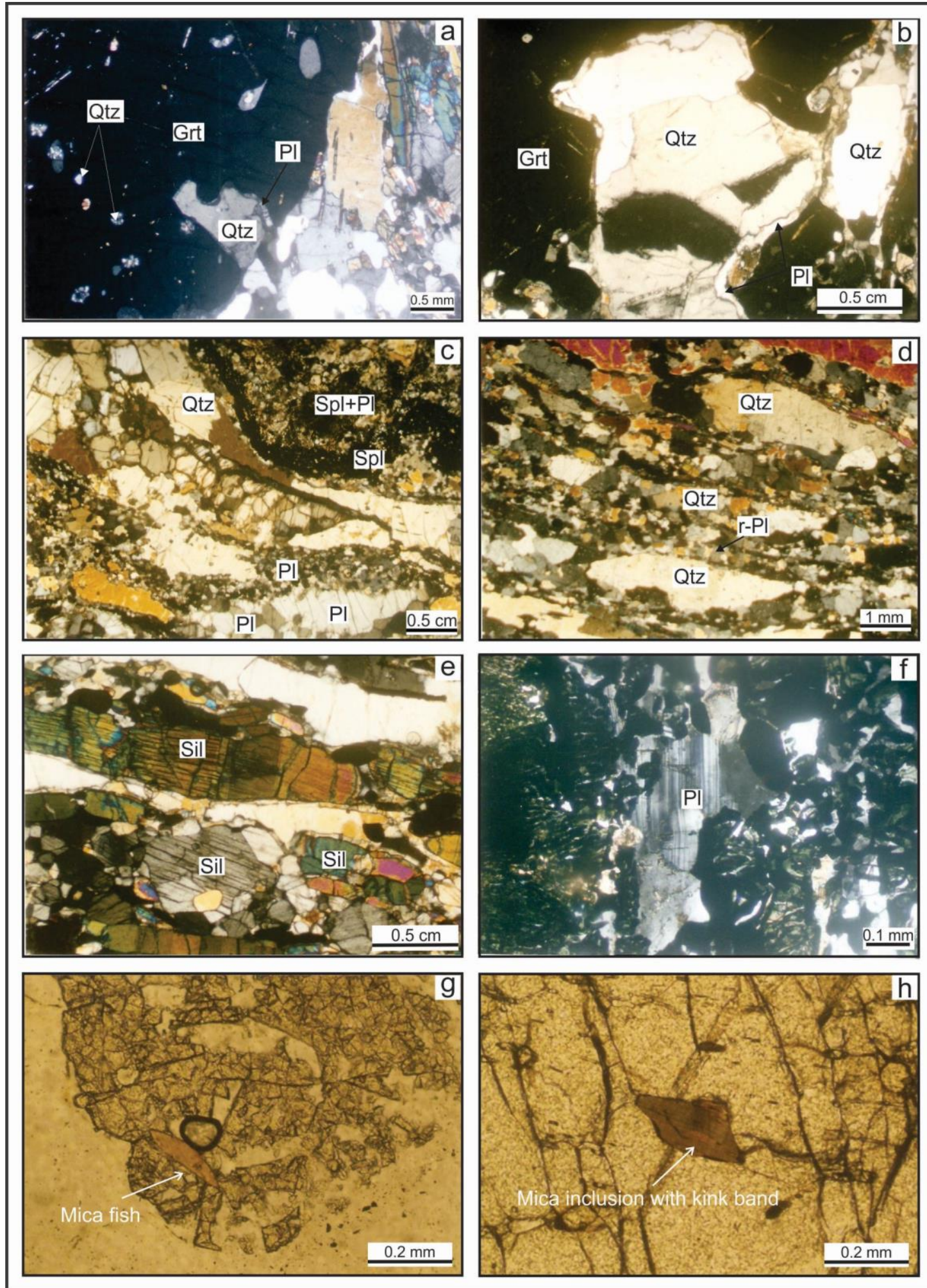

Fig. 7. Photomicrographs of minerals in khondalitic mylonites. (a) Quartz inclusions in garnet porphyroblast. Note the thin plagioclase rim around the quartz inclusions. (b) Quartz inclusion in garnet (centre of the photograph). Note the thin film of plagioclase around quartz. (c) An elongated quartz ribbon rapping around garnet pseudomorph (upper left corner). (d) Stretched quartz ribbons and dynamically recrystallized fine plagioclase. (e) Strained sillimanite with subgrains. (f) Strained plagioclase (centre) with deformation twin. (g) An early mica fish, probably related to early shearing along the WHBSZ, included in the rim of a garnet. (h) Mica inclusion showing kink band in garnet. Kinking of the mica inclusion may either be related to $D_{1}$ deformation or to the early phase of $D_{2}$. 
due to the fact that the Nawalapitiya mylonite, which contains more quartzo-feldspathic layers (Fig. 8), has a different composition than the other spinel-bearing mylonites. This Nawalapitiya spinel-bearing mylonite occurs closely associated with sapphirine-bearing metapelite which has attained UHT metamorphic conditions (Dharmapriya et al., 2015). That means, before the formation of spinel-bearing mylonites, the original khondalitic mylonite containing sillimanite and garnet had formed under HT to UHT granulite facies conditions, similar to the khondalitic mylonites at Habarana, Lenadora and Palapawala. sillimanite and garnet porphyroblasts, may indicate that these intergrowths have developed along the mylonitic foliations and shear bands surrounding garnet porphyroblasts (Figs. 3b,d,f, 4b,d,f, 5e, 6, 8b,c; see also Hiroi et al., 1997). This indicates that the elements $(\mathrm{Fe}$ and $\mathrm{Mg}$ ) needed for growth of spinel have been derived from near by sources, most probably the garnet porphyroblasts themselves (see also Hiroi et al., 1997). It is clear that these spinel-plagioclase assemblages have formed along the above mentioned shear planes in these mylonites as a result of fluids migrated along the WHBSZ after the

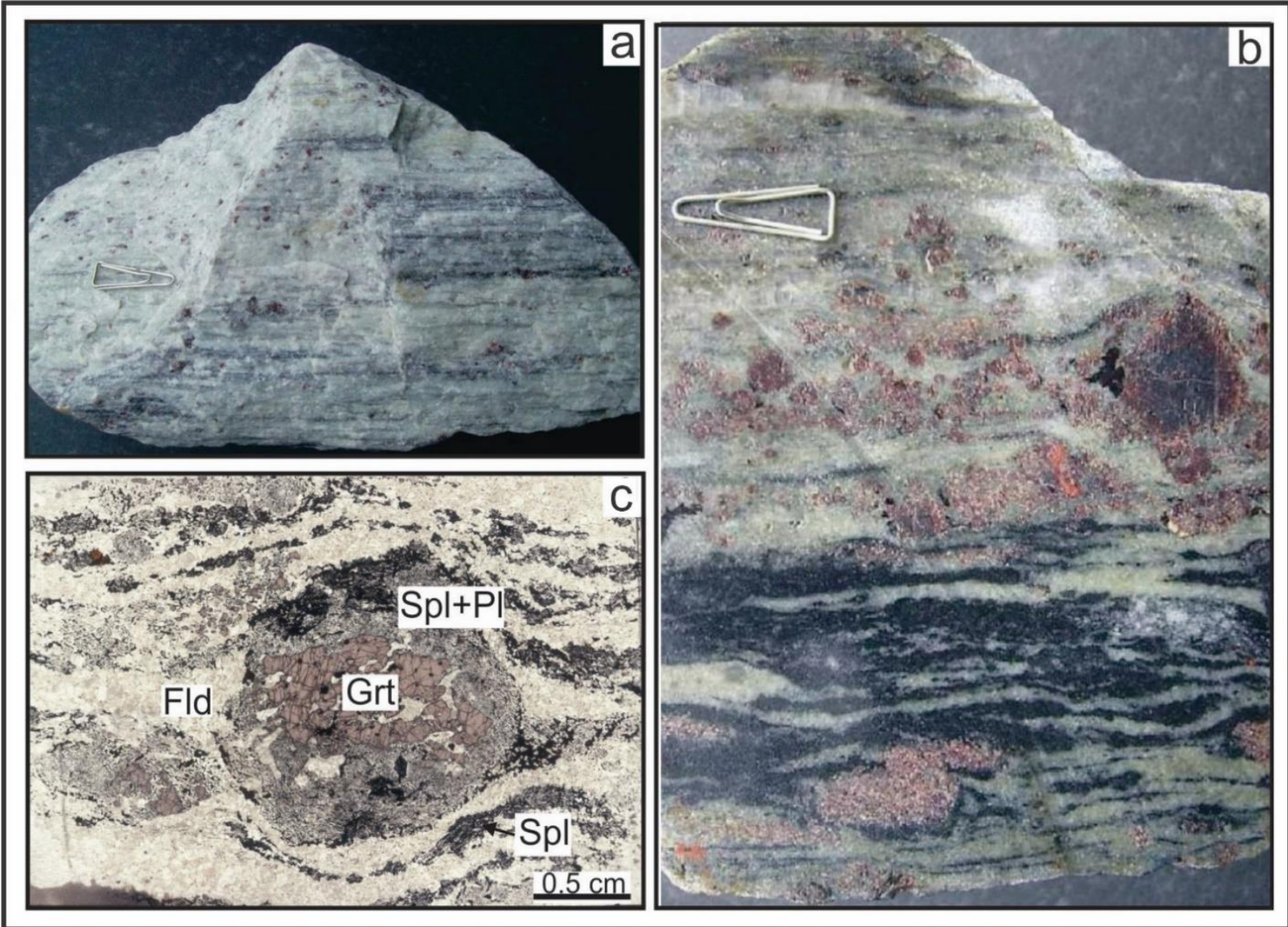

Fig. 8. Spinel-bearing khondalitic mylonite at the Greenwood quarry, Nawalapitiya. (a) Hand specimen showing highly sheared pelitic rock with strongly developed stretching lineation. (b) Hand specimen showing spinel-bearing khondalitic mylonite at the same quarry showing spinel-free (upper part) and spinel-bearing layers (lower part). (c) Photomicrograph showing partial replacement of garnet by spinelplagioclase symplectite and replacement of matrix sillimanite by spinel.

Careful observations of the mesoscopic and microscopic features of the spinel-plagioclase symplectite intergrowths in these spinel-bearing khondalitic mylonites, replacing both matrix cessation of the shearing as these spinel-plagioclase symplectites preserve their delicate texture (Figs. 4b,d,f, 5e, 6). Hiroi et al. (1997) and Dharmapriya et al. (personal communication) 
suggested that the growth of spinel in the pelitic rocks they have investgated is related to late fluids. As all these rocks have no or rare hydrous minerals such as biotite, the fluids which were responsible for growth of spinel-plagioclase assemblages must be rich in $\mathrm{CO}_{2}$ (see also Hiroi et al., 1997). Migration of $\mathrm{CO}_{2}$-rich fluids along the WC/HC boundary shear zone has been described by Binu-Lal et al. (2003). The formation of spinel-plagioclase symplectites replacing garnet cannot be related to any retrograde garnet breakdown reaction since this type of replacement assemblages may form from garnet in the presence of $\mathrm{CO}_{2}$-rich fluids as observed in the altered wall rocks of vein graphite deposits (Kehelpannala unpublished data).

In almost all studied khondalitic mylonites, plagioclase occurs in three modes. The first mode is the plagioclase of the peak metamorphic assemblage (Fig. 4a, c), while the second mode is rim plagioclase around quartz inclusion in garnet (Fig. 7a, b), which is very common in most of the Sri Lankan granulites (e.g. Raase and Schenk, 1994; Hiroi et al., 1994). The third mode is the plagioclase produced in the spinel-plagioclase symplectite (Fig. 7a-d). Most plagioclase grains show stable grain contacts with each other with sharp grain boundaries. Some fine-grained plagioclase grains with polygonal shape seem to have formed by dynamic recrystallization (Fig. 7c, d) during shearing along the WHBSZ and form elongated recrystallized aggregates (Fig. 7d). Some relics of strained peak metamorphic plagioclase present in the matrix show undulose extinction, and some other plagioclase grains have deformation twins (Fig. 7f), which are related to post-shearing deformation at relatively lower temperatures. This is confirmed by the presence of subgrains in some quartz grains (Figs. 7c,d) and sillimanite (Fig. 7e).

\section{SEMIPELITIC MYLONITES}

Metasemipelitic gneiss occurring along the WHBSZ make another type of mylonite. This type of mylonite is found all along the boundary shear zone, which is well-exposed in outcrops at Getambe, Digana, many places along the Kandy-
Randenigala road, Kande Handiya, Nalanda, Dambulla and Habarana. This type of semipelitic mylonites contains garnet, biotite, sillimanite, quartz and feldspar as major minerals, and this mineral assemblage indicates that these mylonites have formed under HT granulite facies conditions. Shear sense indicators, such as $\delta$-type objects, asymmetric folds and sheath folds are found in the semipelitic mylonite exposed at Kande Handiya (Figs. 9a,b) and Getambe (Figs. 9c,d) demonstrate that the movement along the WHBSZ is from top-to-the SSE. Where the shear strain along the WHBSZ is very severe, metapelitic rocks become ultramylonite in which all the minerals are very fine-grained (Fig. 10a; Kehelpannala, 2016a) due to severe strain.

\section{QUARTZO-FELDSPATHIC MYLONITE (STRIPED GNEISS)}

The quartzo-feldspathic mylonites exposed along the $\mathrm{WC} / \mathrm{HC}$ boundary shear zone are the main metagranitoids exposed at Digana (the Digana granite) and around the Victoria dam (the Victoria granite). These rocks are strongly sheared forming a well-developed mylonitic foliation and a strong stretching lineation (Figs. 10b, 11; Kehelpannala, 1987, 1991, 1997; Voll and Keinschrodt, 1991; Binu-Lal et al., 2003) and extend from Digana and Victoria towards north through Wawinna, Wattegama, Matale, Nalanda and Dambulla, and from there, they run towards NE (Fig. 1). From Digana-Victoria, these metagranitoid mylonites extend towards SW of the country through Kotmale, Ulapane, Nawalapitiya and Ginigathena (Fig. 1). From the Digana-Victoria areas, these mylonites runs towards SE along the WHBSZ as described earlier. These rocks are pale grey in colour and mainly contain K-feldspar (perthite), quartz, plagioclase, garnet, hornblende, sphene and opaques (Binu-Lal et al., 2003). In these rocks, biotite, pyroxene and apatite occur as accessory phases. The difference between these two rock types is the presence of graphite in the Digana metagranitoid and the lack of this mineral in the Victoria metagranitoid. These metagranitoids are now striped gneisses (Fig. 11) with mylonitic foliations defined by 

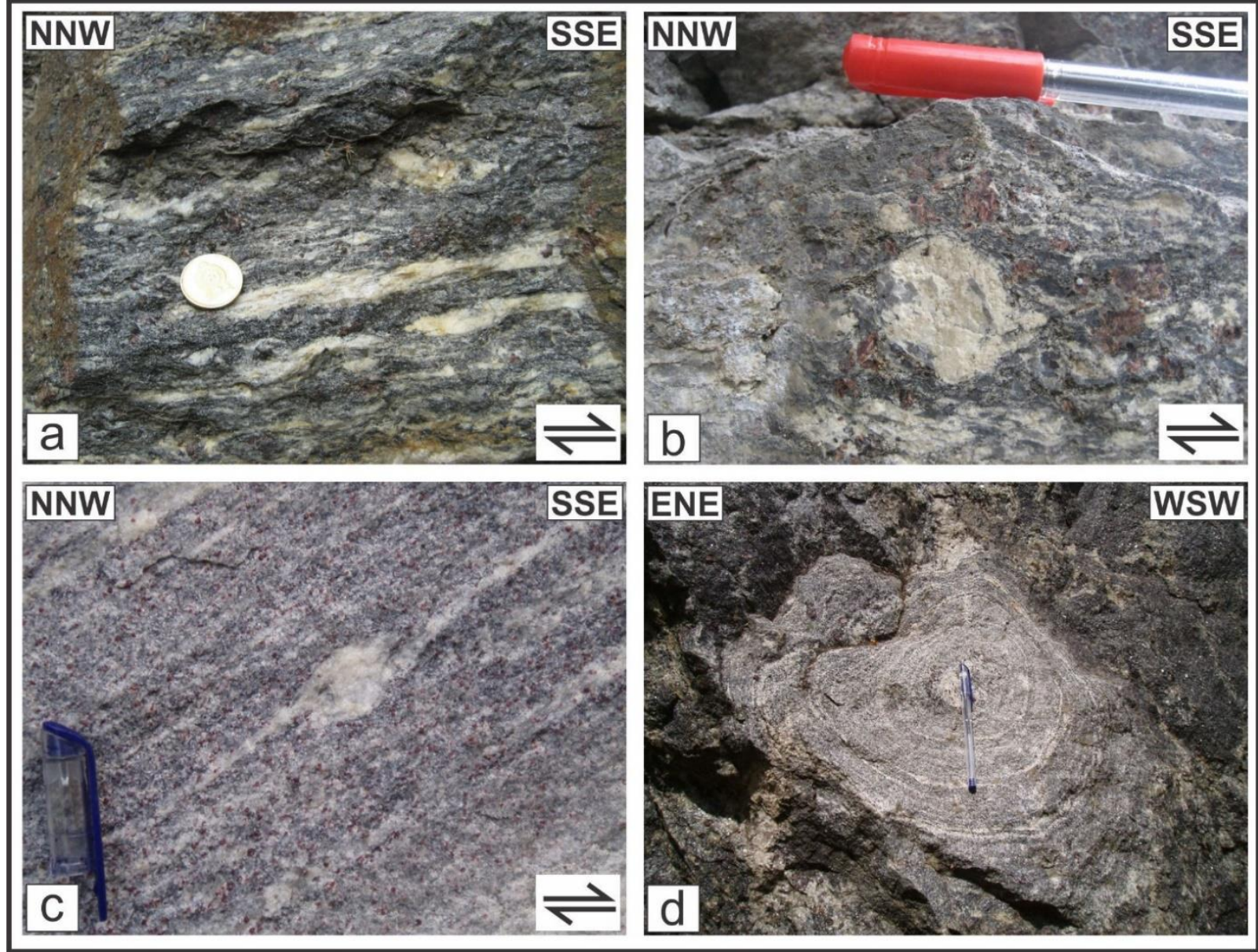

Fig. 9. Field photographs from metasemipelitc mylonites occurring along the WHBSZ (all photographs from Kehelpannala, 2016b). (a) Semipelitic mylonite exposed at a road outcrop along the Randenigala road, $225 \mathrm{~m}$ from the Kande Handiya junction towards Adikarigama. The rotated patial melt patch below the coin shows top-to-the SSE movement. Note very fine-grained biotite and dynamically recrystallized feldspar. (b) A rotated $\delta$-object (a clast of partial melt) showing the SSE movement of the WC over the HC. The same outcrop as in (a). Felsic patches seen in $(a)$ and $(b)$ are sheared partial melting products. (c) An asymmetric fold showing top-to-the SSE movement, Getambe quarry, SW of Kandy. (d) Sheath fold found in pelitic mylonite showing top-to-the SSE movement, Getambe quarry, SW of Kandy.

flattened and elongated fine-grained aggregates of recrystallized feldspar and hornblende, and with strongly flattened and stretched quartz ribbons more than $10 \mathrm{~cm}$ long (Figs. 10b, 11). Strongly lineated graphite is found in the Digana metagranitoid mylonite (Binu-Lal et al., 2003). Graphite flakes in the Digana striped gneiss (mylonite) range from $<1 \mathrm{~mm}$ to several $\mathrm{mm}$, and some large flakes are even larger than $2 \mathrm{~cm}$. The basal planes of all the disseminated graphite flakes are parallel to the mylonitic foliation plane in the host metag ranitoid mylonite (Binu-Lal et al., 2003). Deformed graphite crystals are highly elongated parallel to the stretching lineation in the host metagranitoid mylonite. Some parts of these metagranitoids have undergone severe grain size reduction forming ultramylonites (Fig. 10b; Kehelpannala, 2016a).

In addition to these, a quartzo-feldspathic mylonite with a very strong flattening foliation and a very long stretching lineation (Fig. 11b) occurs in marble around Digana, Wawinna, Wattegama, Ukuwela and Nalanda along the WHBSZ (Fig. 1), which represents a strongly sheared and metamorphosed graphic granite (Kehelpannala and Ranaweera, 2007). Probably, these graphic granites had intruded along the $\mathrm{WC} / \mathrm{HC}$ boundary 


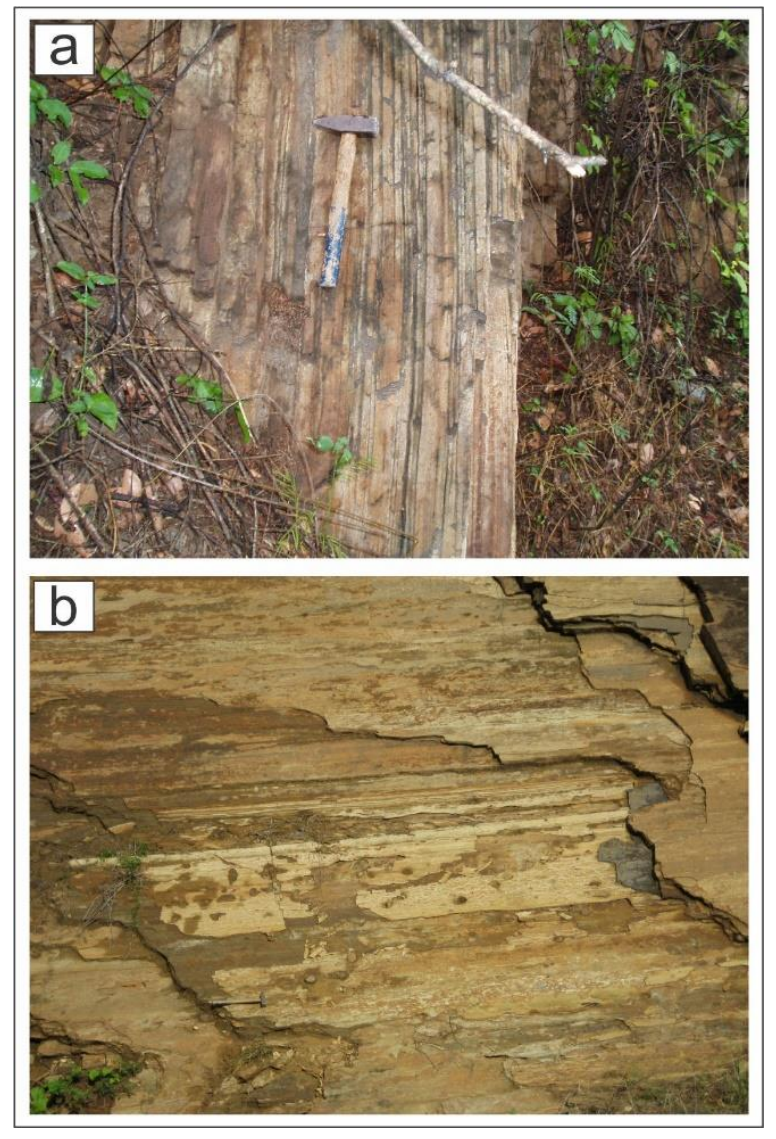

Fig. 10. Field photographs showing ultramylonite found along the WHBSZ (all photographs from Kehelpannala, 2016b). (a) Metapelitic ultramylonite along the $\mathrm{WC} / \mathrm{HC}$ boundary shear zone exposed at the $16 \mathrm{th} \mathrm{km}$ post on the Randenigala road. Note nearly vertical mylonitic foliation. (b) Metagranitoid ultramylonite at Rambukwella on the Karalliyadda-Mahiyangana road. Note strongly, dynamically recrystallized, elongated fine-grained aggregates of feldspar and quartz plates, defining both the stretching lineation and mylonitic foliation.

shear zone and have later been sheared by the deformation related to the shear zone.

All the above metagranitoids had intruded HC sediments consisting of quartzite, pelites, (now khondalite), semipelites and marble during Palaeoproterozoic (Baur et al. 1991; Kröner et al., 2017,2018 ) as mentioned earlier and had undergone granulite to UHT metamorphism and strong shearing during the $\mathrm{D}_{2}$ non-coaxial deformation related to the first collision between the WC and the HC during Neoproterozoic (Kehelpannala, 2004, 2016a,b). Later, these rocks have undergone severe retrogression (e.g. Baur et al., 1991; Binu-Lal et al., 2003) disappearing granulite facies minerals such as pyroxene. However, at some places along the folded WHBSZ, the meta-granitoid mylonite is charnockitic, containing orthopyroxene and clinopyroxene, as is seen around Gurudeniya, Kivullinda, Kanda Handiya and Nawalapitiya (e.g. in the Greenwood Estate). Some of these metagranitoid mylonites had been intruded by mafic dykes during Neoproterozoic (e.g. Kröner et al., 2017, 2018) before the shearing and HT to UHT granulite facies metamorphism as can be seen in the Victoria and Nawalapitiya metagranitoid mylonites. Some of these metagranitoid mylonites have undergone late shearing along some small, discrete ductile shear zones as is seen at Digana (e.g. Binu-Lal et al., 2003).

Recently, Athurupana et al. (2019) studied the metagranitoid mylonitic gneiss at Digana and concluded that the $\mathrm{D}_{2}$ deformation (of Kehelpannala, 1997) indicative of strong coaxial deformation predated the peak metamorphism of the $\mathrm{HC}$ and that there is no sign of penetrative deformation coeval with peak metamorphism. This conclusion is incorrect as they used pressure and temperature conditions related to retrograde garnet break-down reactions (e.g. garnet + quartz $\rightarrow$ Plagioclase + orthopyroxene) to estimate peak metamorphic condition of the HC. These retrograde garnet breakdown reactions are very common in Sri Lankan granulites and record temperature and pressure of $\sim 650^{\circ} \mathrm{C}$ and $\sim 5-6.5 \mathrm{kbar}$, respectively (e.g. Schenk et al, 1991; Kehelpannala, 1999). In the Digana metagranitoid mylonite, scapolite has formed from plagioclase due to alteration by late fluids related to some cross-cutting calcite-sulphide veins (Kehelpannala, 2016a), and therefore, scapolite in this rock is not a product of peak metamorphism. Athurupana et al. (2019) erroneously interpreted that this scapolite is a product of peak granulite facies metamorphism, and, accordingly, estimated P-T conditions based on the P-T estimates of Newton and Goldsmith (1976). Although numerous new P-T data on HT to UHT granulite metamorphism from Sri Lankan granulites are available (e.g. Dharmapriya et al., 2017a and references there 

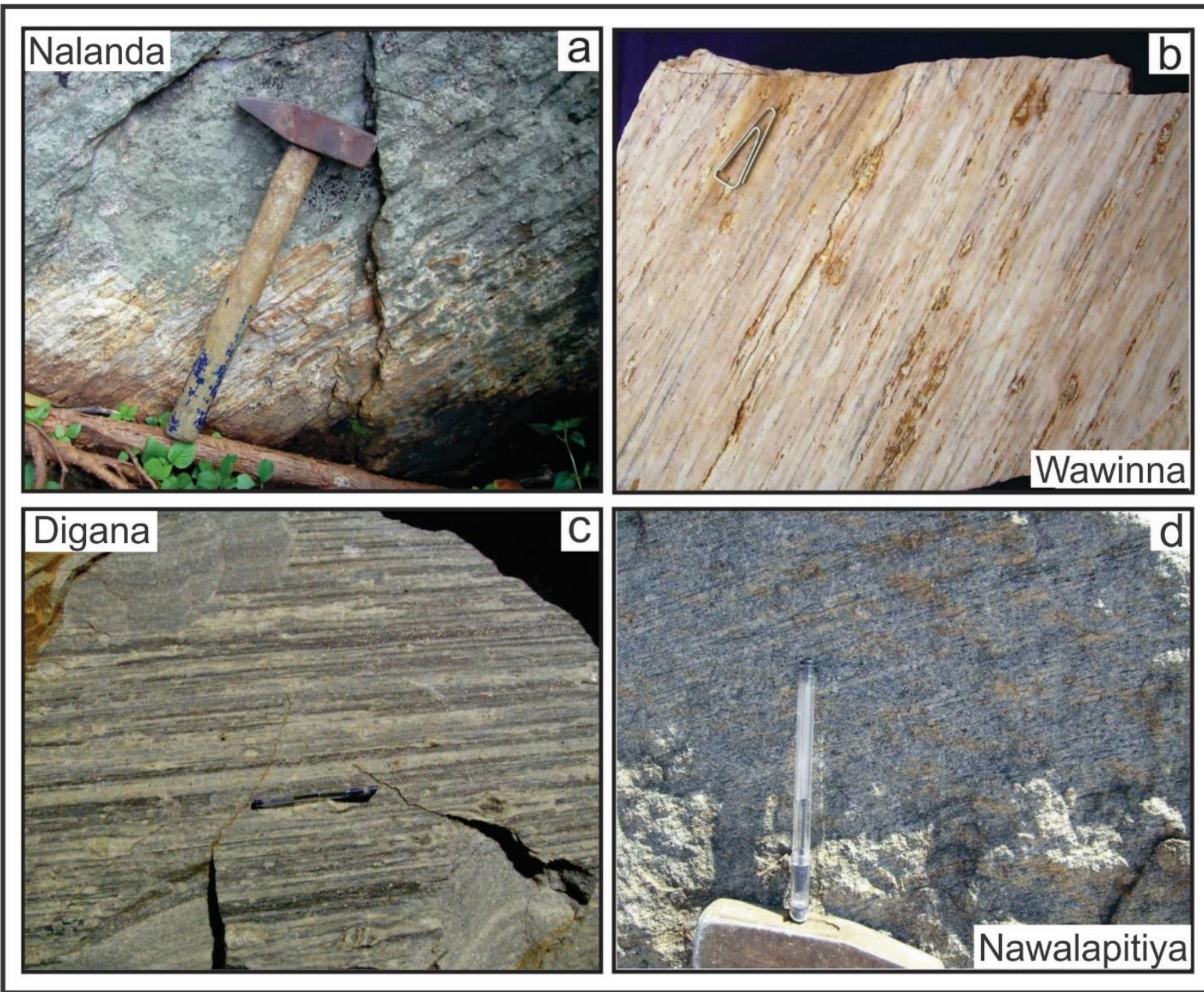

Fig. 11. Field photographs showing quartzo-feldspathic mylonites (striped gneisses) exposed along the WC/HC boundary. (a) Striped gneiss at Nalanda. (b) Mylonitized graphic granite at Wawinna (taken from Kehelpannala and Ranaweera, 2007). (c) Mylonitized metagranitoid at Digana (taken from Kehelpannala, 2007). (d) Mylonitized metagranitoid at Nawalapitiya. Note strong mylonitic foliation and stretching lineation in all photographs.

in), Athurupana et al. (2019) did not use these data to estimate correct P-T conditions of the peak metamorphism. This late scapolite in the Digana metagranitoid mylonite and their erroneous P-T estimates led Athurupana et al. (2019) to conclude that $\mathrm{D}_{2}$ deformation producing quartz ribbons has taken place before the peak metamorphism of the HC. Here we again emphasize that the WHBSZ has formed during the second phase of $\mathrm{D}_{2}$ non-coaxial deformation accompanying $\mathrm{HT}$ to UHT granulite metamorphism related to the first collision between the $\mathrm{WC}$ and the $\mathrm{HC}$ as already mentioned.

\section{CONCLUSIONS}

Khondalitic, semipelitic, and metagranitoid (striped gneiss) mylonites studied along the WC/HC boundary shear zone show mesoscopic to microstructural evidence, such as rotated garnet porphyroblasts, $\mathrm{C}^{\prime}$ type shear band foliations, $\delta$-type and $\sigma$-type objects, asymmetric and rotated boudins, sheath folds and asymmetric folds, for dominant non-coaxial ductile flow during shearing. The presence of snowball type garnets in pelitic mylonites at Habarana, Lenadora, Palapatwala and Nawalapitiya also indicates simple shear deformation. The presence of domino type 
garnet porphyroclast and $\sigma$-type garnet clasts in some of the khondalitic mylonites further support dominant non-coaxial ductile flow associated with the WHBSZ. Although striped gneisses found along the WHBSZ are free of visible asymmetric structures, the strong mylonitic foliation and long stretching lineation in these rocks are, however, consistent with dominant non-coaxial folw (Passchier and Coelho, 2006). This type of striped gneisses usually lacks shear sense indicators as stretching of grains takes place by dislocation or diffusion creep (Passchier and Coelho, 2006). Ultramylonite formed from these metagranitoids further supports the non-coaxial nature of the ductile flow along the WHBSZ.

All these mesoscopic to microstructural evidences and previous studies on mesoscopic structures in the high-grade mylonites found along the WHBSZ (Kehelpannala, 2003, 2004, 2006, 2016b; Kehelpannala and Ranaweera, 2007; Ranaweera, 2008) show top-to-the SSE movement associated with the WHBSZ indicating that the WC has been emplaced from NNW (present orientation) on top of the HC (Kehelpannala, 2003, 2004, 2006, 2016a). These findings do not support the idea of Kriegsman (1993, 1994, 1995) that his KC was emplaced from SSE on the HC. As suggested by Kehelpannala $(2006,2016 \mathrm{~b})$ almost all the ultrahigh temperature assemblages found in Sri Lanka (see Dharmapriya, 2017: Osanai et al., 2016b; Touret et al. 2019 and references therein) are located along the WHBSZ, indicating that the shearing along this boundary suture zone occurred during high temperature to UHT granulite facies conditions $\left(\mathrm{T}=850-1005^{\circ}\right.$ $\mathrm{C}, \mathrm{P}=0.8-1.2 \mathrm{GPa}$ ) as expected from the arc accretion model of Kehelpannala (2004, 2016a,b). All the available evidence suggests that the WHBSZ has formed during the second phase of $\mathrm{D}_{2}$ non-coaxial deformation accompanying high temperature to UHT granulite facies metamorphism related to the first collision between the WC and the HC. Subsequent $\mathrm{D}_{5}$ ductile deformation during the second collision between the $\mathrm{WC} / \mathrm{HC}$ unit and the VC (Kehelpannala, 2004) has severely affected and folded the WHBSZ, causing it to repeat and reappear in many areas as explained earlier. $D_{5}$ deformation is also responsible for post-WHBSZ modification and deformation shown by the development of subgrains in some minerals, such as sillimanite and quartz.

\section{ACKNOWLEDGEMENTS}

Part of the work reported in this paper was carried out at the former Institute of Fundamental Studies (IFS), Kandy, Sri Lanka by LVR for his master programme under the supervision of KVWK, while both authors were researchers at IFS. KVWK's subsequent field studies and data collection in Sri Lanka for this paper were selfsponsored. Anura Pathirana and Sanath Opatha of IFS are thanked for field assistance and help in thin section preparation. We thank the journal's reviewers for their constructive comments and suggestions. This paper is a contribution to the IGCP Project 648 on "Supercontinent Cycles and Global Geodynamics".

\section{REFERENCES}

Athurupana, B., Muto, J. and Nagahama, H. (2019) Development of Quartz Ribbons in Felsic Granulites Under Strong Coaxial Deformation in the Highland Complex of Sri Lanka. In The Structural Geology Contribution to the Africa-Eurasia Geology: Basement and Reservoir Structure, Ore Mineralisation and Tectonic Modelling, Advances in Science, Technology and Innovation. F. Rossetti et al. (eds.) Springer Nature Switzerland, pp 33-35.

Baur, N., Kröner, A., Todt, W., Liew, T.C. and Hofmann, A.W. (1991) U-Pb isotopic sys $\neg$ tematics of zircons from prograde and retrograde transition zones in high-grade orthogneisses, Sri Lanka. Journal of Geology, 99: 527-545.

Bell, T.H. and Johnson, S.E. (1992) Shear sense: a new approach that resolves conflicts between criteria in metamorphic rocks. Journal of Metamorphic Geology, 10: 99-124.

Berger, A.R. and Jayasinghe, N.R. (1976) Precambrian structure and chronology in the Highland Series of Sri Lanka. Precambrian Research, 3: 559576.

Binu-Lal, S.S., Kehelpannala, K.V.W., Satish-Kumar, M. and Wada, H. (2003) Multistage graphite precipitation through protracted fluid flow in sheared metagranitoid, Digana, Sri Lanka: Evidence from stable isotopes. Chemical Geology, 197: 253-270.

Braun, I. and Kriegsman, L.M. (2003) Proterozoic crustal evolution of southernmost India and Sri Lanka. In Proterozoic East Gondwana: Supercontinents Assembly and Breakup. Yoshida, M. and 
Windley, B.F. (eds.) Special Publications, Geological Society, London, pp 169-203.

Büchel, G. (1994) Gravity, magnetic and structural patterns at the deep-crustal plate boundary zone between West- and East-Gondwana in Sri Lanka. Precambrian Research, 66: 77-91.

Chetty, T.R.K. (1996) Proterozoic shear zones in southern granulite terrain, India. In The Archaean and Proterozoic terrains in Southern India within East Gondwana. Santosh, M and Yoshida, M (eds.) Gondwana Research Group Memoir - 3, pp 77-89.

Chetty, T.R.K. and Bhaskar Rao, Y.J. (2006) Strain pattern and deformational history in the eastern part of the Cauvery shear zone, southern India. Journal of Asian Earth Sciences, 28: 46-54.

Cooray, P.G. (1961) The Geology of the Country around Rangala. Memoir 2, Ceylon Department of Mineralogy. 138 pp.

Cooray, P.G. (1978) Geology of Sri Lanka. Proceedings 3rd Regional Conference, Geology and Mineral Resources of SE Asia, Bangkok, 14-18 November, pp 107-110.

Cooray, P.G. (1994) The Precambrian of Sri Lanka: a historical review. Precambrian Research, 66: 3-18.

Dharmapriya, P.L. (2017) Understanding of ultrahightemperature lower crustal granulites: Implications for P-T-t path and structural evolution of the Highland Complex, Sri Lanka. Journal of Geological Society of Sri Lanka, 18: 129-147.

Dharmapriya, P.L., Malaviarachchi, S.P.K., Galli, A., Su, B-X., Subasinghe, N.D. and Dissanayake, C.B. (2015) Rare evidence for formation of garnet + corundum during isobaric cooling of ultrahigh temperature metapelites: New insights for retrograde $\mathrm{P}-\mathrm{T}$ trajectory of the Highland Complex, Sri Lanka. Lithos, 220-223: 301-317.

Dharmapriya, P.L., Malaviarachchi, S.P.K., Sajeev, K. and Zhang, C. (2016) New LA-ICPMS U-Pb ages of detrital zircons from the Highland Complex: insights into late Cryogenian to early Cambrian (ca. 665-535 Ma) linkage between Sri Lanka and India. International Geology Review, 58: 1856-1883.

Dharmapriya, P.L., Malaviarachchi, S.P.K., Kriegsman, L.M., Galli, A., Sajeev, K. and Zhang, C. (2017a) New constraints on the P-T path of HT/UHT metapelites from the Highland Complex of Sri Lanka. Geoscience Frontiers, 8: 1405-1430.

Dharmapriya, P.L., Malaviarachchi, S.P.K., Kriegsman, L.M., Sajeev, K., Galli, A., Osanai, Y., Subasinghe, N.D and Dissanayake, C.B. (2017b) Distinct metamorphic evolution of alternating silica-saturated and silica-deficient microdomains within garnet in ultrahigh-temperature granulites: An example from Sri Lanka. Geoscience Frontiers, 8: 1115-1133.

Dissanayake, C.B. and Munasinghe, T. (1982) A Plate tectonic model for the geologic evolution of Sri Lanka. Journal of Geological Society India, 23: 369-380.

Fernando, L.J.D. (1947) some aspects of the geology of Ceylon. Proceedings Ceylon Association for Advancement of Science, ii: 69-83.
Fossen, H., Geane Carolina, G. and Cavalcante, G. (2017) Shear zones - A review. Earth-Science Reviews, 171: 434-455.

Geological Map of Sri Lanka. (1982) Geological Survey Department, Colombo, Scale 8 miles $=1$ inch.

Gray, D. R. (1979) The geometry of crenulation folds and their relationship to crenulation cleavage. Journal of Structural Geology, 1: 187-206.

Hatherton, T., Pattiarachchi, D.B. and Ranasinghe, R.B. (1975) Gravity map of Sri Lanka, 1:1,000,000. Professional Paper 3, Geological Survey Department of Sri Lanka. pp 39.

He, X-F., Santosh, M., Tsunogae, T., Malaviarachchi, S.P.K. and Dharmapriya, P.L. (2016) Neoproterozoic arc accretion along the 'eastern suture' in Sri Lanka during Gondwana assembly. Precambrian Research, 279: 57-80.

Hiroi, Y., Yoshida, M. and Vitanage, P.W. (1987) Relict kyanite in the Highland and Southwest gneisses in Sri Lanka; evidence of prograde metamorphism and a characteristic common with the LützowHolm Bay complex in East Antarctica. Special Publication 3, Geological Society of Sri Lanka. pp 28.

Hiroi, Y., Ogo, Y. and Namba, K. (1994) Evidence for prograde metamorphic evolution of Sri Lanka: pelitic granulites and implications for the development of continental crust. Precambrian Research, 66: 254-263.

Hiroi, Y., Motoyoshi, Y., Shiraishi, K. and Mathavan, V. (1997) Local formation of Hercynite - Plagioclase symplectite after Garnet and sillimanite in khondalite from Habarana, Sri Lanka: Mineral Textures. Proceedings NIPR Symposium, Antarctic Geoscience, 10: 153-164.

Hölzl, S., Köhler, H., Kröner, A., Jaeckel, P. and Liew, T.C. (1991) Geochronology of the Sri Lankan basement. In The Crystalline Crust of Sri Lanka, Part I, Summary of Research of the German-Sri Lankan Consortium. Kröner, A. (ed.), Professional Paper 5, Geological Survey Department, Sri Lanka, pp 237-257.

Hölzl, S., Hofmann, A.W., Todt, W. and Köhler, H. (1994) U-Pb Geochronology of the Sri Lankan basement. Precambrian Research, 66: 123-149.

Katz, M.B. (1971). The Precambrian metamorphic rocks of Ceylon. Geologishe Rundschau, 60: 15231549.

Katz, M. B. and Premoli, C. (1979) India and Madagascar in Gondwanaland based on matching Precambrian lineaments. Nature, 279: 312-315.

Kehelpannala, K.V.W. (1987). The structure, tectonics and hydrogeology of lineaments of Sri Lanka with special reference to the Central Highland, unpublished M.Phil. Thesis, University of Peradeniya, Sri Lanka, 239 pp.

Kehelpannala, K.V.W. (1991) Structural evolution of high-grade terrains in Sri Lanka with special reference to the areas around Dodangaslanda and Kandy. In The Crystalline Crust of Sri Lanka, Part I, Summary of Research of the German-Sri Lankan 
Consortium. Kröner, A. (ed.) Professional Paper 5, Geological Survey Department, Sri Lanka, 69-88.

Kehelpannala, K.V.W. (1997) Deformation of a highgrade Gondwana fragment, Sri Lanka. Gondwana Research, 1: 47-68.

Kehelpannala, K.V.W. (1999) Shear Zone-Controlled Arrested Charnockitization, Retrogression and Metasomatism of High-grade Rocks. Gondwana Research, 2: 573-577.

Kehelpannala, K.V.W. (2003) Structural evolution of the middle to lower crust in Sri Lanka. Journal of Geological Society of Sri Lanka, 11: 45-86.

Kehelpannala, K.V.W. (2004) Arc accretion around Sri Lanka during the assembly of Gondwana. Gondwana Research, 7, No. 4S: 41-46.

Kehelpannala, K.V.W. (2006) The geodynamic evolution of Sri Lanka-A review. Abstract. AGU Fall Meeting, San Francisco, USA.

Kehelpannala, K.V.W. (2007a) Geology of Sri Lanka. Section 3.1, National Atlas of Sri Lanka, Second Edition, Survey Department of Sri Lanka, Colombo, Sri Lanka, pp. 20-23.

Kehelpannala, K.V.W. (2007b) Structure and Tectonics. Section 3.3, National Atlas of Sri Lanka, Second edition. Survey Department of Sri Lanka, Colombo, Sri Lanka, pp. 26-29.

Kehelpannala, K.V.W. (2016a). Intermediate to mafic gneisses of the Wanni Complex of Sri Lanka around Kandy and their deformation-controlled migmatization. In Geological Structures along the Wanni and Highland Complex Boundary, Central Sri Lanka, Guide Book on Field Geology Workshop 20-21, August 2016. Malaviarachchi, S.P.K. (ed.) Special Publication 11, Geological Society of Sri Lanka, pp 6-23.

Kehelpannala, K.V.W. (2016b) Strongly deformed and mylonitized granulites of the Highland Complex of Sri Lanka along its boundary with the Wanni Complex. In Geological Structures along the Wanni and Highland Complex Boundary, Central Sri Lanka, Guide Book on Field Geology Workshop 20-21, August 2016. Malaviarachchi, S.P.K. (ed.) Special Publication 11, Geological Society of Sri Lanka, pp 21-49.

Kehelpannala, K.V.W. (2017). Post-metamorphic Kmetasomatism of high-grade rocks - A new cconcept in geology. Journal of the Geological Society of Sri Lanka, 18: 01-19.

Kehelpannala, K.V.W. and Ranaweera, L.V. (2007) Structural and kinematic evolution of a possible Pan - African suture zone in Sri Lanka. Proceedings of the 4th International Convension on Gondwana to Asia and IAGR 2007, Fukuoka, Japan, November 8-13, 2007.

Kitano, I., Osanai, Y., Nakano, N., Adachi, T. and Fitzsimons, I.C.W. (2018) Detrital zircon and igneous protolith ages of high-grade metamorphic rocks in the Highland and Wanni Complexes, Sri Lanka: their geochronological correlation with southern India and East Antarctica. Journal of Asian Earth Sciences, 156: 122-144.
Kleinschrodt, R. (1994) Large-scale thrusting in the lower crustal basement of Sri Lanka. Precambrian Research, 66: 39-57.

Kleinschrodt, R. (1996) Strain localization and largescale block rotation in the lower continental crust, Kataragama area, Sri Lanka. Terra Nova, 8: 236244.

Kleinschrodt, R., Voll, G. and Kehelpannala, K.V.W. (1991) A layered basic intrusion, deformed and metamorphosed in granulite facies of the Sri Lankan basement. Geologische Rundschau, 80: 779-800.

Kriegsman, L. (1991) Structural geology of the Sri Lankan basement - a preliminary review. In The crystalline crust of Sri Lanka, Part I, Summary of Research of the German-Sri Lankan Consortium. Kröner, A. (Ed.) Prof. Paper 5, Geological Survey Department, Sri Lanka, pp 52-68.

Kriegsman, L.M. (1993) Geodynamic evolution of the Pan-African lower crust in Sri Lanka. Geologica Ultraiectina, University of Utrecht, The Netherlands, 114, 207.

Kriegsman, L. (1994) Evidence for nappe tectonics in the high-grade basement of Sri Lanka: Pan-African terrane assembly in the lower crust. Precambrian Research, 66: 59-76.

Kriegsman, L. (1995) The Pan-African events in East Antarctica: a review from Sri Lanka and the Mozambique Belt. Precambrian Research, 75: 263277.

Kreigsman, L. and Schumacher, J.C. (1999) Petrology of sapphirine-bearing and associated granulites from central Sri Lanka. Journal of Petrology, 40: 1211-1239.

Kröner, A., Williams, I.S., Compston, W., Vitanage, P.W. and Perera, L.R.K. (1987) Zircon ion microprobe dating of high-grade rocks in Sri Lanka. Journal of Geology, 95: 775-791.

Kröner, A. (1991) African linkage of Precambrian Sri Lanka. Geologische Rundschau, 80: 429-440.

Kröner, A. and Williams, I.S. (1993) Age of metamorphism in the high-grade rocks of Sri Lanka. Journal of Geology, 101: 513-521.

Kröner, A. and Jaeckel, P. (1994) Zircon ages from rocks of the Wanni Complex, Sri Lanka. Journal of Geological Society of Sri Lanka, 5: 41-57.

Kröner, A., Cooray, P.G., and Vitanage, P.W. (1991) Lithotectonic subdivision of the Pre-cambrian basement in Sri Lanka. In The Crystallin Crust of Sri Lanka, Part 1. Summary of Research of the German-Sri Lankan Consortium. Kröner, A. (ed.) Professional paper 5, Geological Survey Department, Sri Lanka, pp 5-21.

Kröner A., Jaeckel, P. and Williams, I.S. (1994a) Pbloss patterns in zircons from a high-grade metamorphic terrain as revealed by different dating methods: $\mathrm{U}-\mathrm{Pb}$ and $\mathrm{Pb}-\mathrm{Pb}$ ages for igneous and metamorphic zircons from northern Sri Lanka. Precambrian Research, 66: 151-181.

Kröner, A., Kehelpannala, K.V.W. and Kreigsman, L. (1994b) Origin of compositional banding and causes for crustal thickening in the high-grade 
terrain of Sri Lanka. Precambrian Research, 66: 21-38.

Kröner, A., Kehelpannala, K.V.W. and Hegner, E. (2003) Ca. 700-1000 Ma magmatic events and Grenvillian-age deformation in Sri Lanka: Relevance for Rodinia supercontinent formation and dispersal and Gondwana amalgamation. Journal of Asian Earth Science, 22: 279-300.

Kröner, A., Rojas-Agramonte, Y., Kehelpannala, K.V.W., Zack, T., Hegner, E., Geng, H.Y., Wong, J. and Barth, M. (2013) Age, Nd-Hf isotopes, and geochemistry of the Vijayan Complex of eastern and southern Sri Lanka: A Grenville-age magmatic arc of unknown derivation. Precambrian Research, 234: 288-321.

Kröner, A., Liu, S. and Kehelpannala, K.V.W. (2017) Late Palaeoproterozoic depositional age for khondalite protoliths in southern India and correlation with Sri Lanka. Gondwana 16 Puzzling out Gondwana Conference, Bangkok, Thailand, 12-21 November 2017, 51-53.

Kröner, A., Kehelpannala, K.V.W., Rojas-Agramonte, Y. and Xie, H. (2018) The Palaeoproterozoic Highland Complex of Sri Lanka and mafic dykes: No Neoproterozoic accretionary complex and doublesided subduction of oceanic crust. Proceedings of the International Association for Gondawana Research 2018 Convention \& 15th International Conference on Gondwana to Asia. Xi'an, China, September 24-28, 2018, 31-33.

Malaviarachchi, S.P.K. and Dharmapriya, P.L. (2015) Revisiting Ultrahigh Temperature Granulites of Sri Lanka: New Prograde and Retrograde Mineral Textures from the Highland Complex. Journal of the Indian Institute of Science, 95 (2): 159-172.

Milisenda, C.C., Liew, T.C., Hofmann, A.W. and Kröner, A. (1988) Isotopic mapping of age provinces in Pre-cambrian high-grade terrains: Sri Lanka. Journal of Geology, 96: 608-615.

Milisenda, C.C. (1991). Development of the continental crust: A study of the high-grade terrain of Sri Lanka. Ph.D. thesis, University of Mainz, Germany.

Milisenda, C.C., Liew, T.C., Hoffmann, A.W. and Köhler, H. (1994) Nd isotopic mapping of the Sri Lanka basement: update, and additional constraints from $\mathrm{Sr}$ isotopes. Precambrian Research, 66: 95110.

Newton, R.C. and Goldsmith, J.R. (1976) Stability of the end-member scapolites: $3 \mathrm{NaAlSi}_{3} \mathrm{O}_{8}-\mathrm{NaCl}$, $3 \mathrm{CaAl} 2 \mathrm{Si}_{2} \mathrm{O}_{8}-\mathrm{CaCO}_{3}, 3 \mathrm{CaAl} 2 \mathrm{Si}_{2} \mathrm{O}_{8}-\mathrm{CaSO}_{4}$. Zeit. für Kristallogaphie, 143: 333-353.

Osanai, Y. (1989). A preliminary report on saphirine/kornerupine granulite from Highland series, Sri Lanka. In Seminar on Recent Advances in Precambrian Geology of Sri Lanka. IFS Kandy, Sri Lanka.

Osanai, Y., Ando, K.T., Miyashita, Y., Kusachi, I., Yamasaki, T., Doyama, D., Prame, W.K.B.N., Jayatilake, S. and Mathavan, V. (2000) Geological field work in the southwestern and central parts of the Highland Complex, Sri Lanka during 19981999, special reference to the highest grade metamorphic rocks. Journal of Geoscience, Osaka City University, 43: 227-247.

Osanai, Y., Sajeev, K., Owada, M., Kehelpannala, K.V.W., Prame, W.K.B.N. and Nakano, N. (2006) Metamorphic evolution of high-pressure and ultrahigh-temperature granulites from the Highland Complex, Sri Lanka. Journal of Asian Earth Sciences, 28: 20-37.

Osanai, Y., Sajeev, K., Nakano, N., Kitano, I., Kehelpannala, K.V.W., Kato, R., Adachi, T. and Malaviarachchi, S.P.K. (2016a) UHT granulites of the Highland Complex, Sri Lanka II: Geochronological constraints and implications for Gondwana correlation. Journal of Mineralogical and Petrological Sciences, 111: 157-169.

Osanai, Y., Sajeev, K., Nakano, N., Kitano, I., Kehelpannala, K.V.W., Kato, R., Adachi, T. and Malaviarachchi, S.P.K. (2016b) UHT granulites of the Highland Complex, Sri Lanka I: Geological and petrological background. Journal of Mineralogical and Petrological Sciences, 111: 145-156.

Passchier, C. (1988) Analysis of deformation paths in shear zones. Geologische Rundschau, 77: 309-318.

Passchier, C. and Coelho, S. (2006) An outline of shear-sense analysis in high-grade rocks. Gondwana Research, 10: 66-76.

Passchier, C.W. and Trouw, R.A.J. (2005) Microtectonics. Second Edition, Springer Verlag, Berlin. $366 \mathrm{pp}$.

Pohl, J.G. and Emmermann, R. (1991) Chemical composition of the Sri Lanka Precambrian basement. In The Crystalline Crust of Sri Lanka, Part 1. Summary of Research of the German-Sri Lankan consortium. Kröner, A. (ed.), Professional Paper 5, Geological Survey Department, Sri Lanka, pp 94123.

Platt, J.P. and Behr, W.M. (2011) Lithospheric shear zones as constant stress experiments. Geology, 39: 127-130.

Raase, P. and Schenk, V. (1994) Petrology of granulite-facies metapelites of the Highland Complex, Sri Lanka: implications for the metamorphic zonation and the P-T path. Precambrian Research, 66: 265-294.

Raith, M., Faulhaber, R., Hoffbauer, R. and Spiering, B. (1991) Characterization of high-grade metamorphism in the southern part of Sri Lanka. In The Crystalline Crust of Sri Lanka, Part 1. Summary of Research of the German-Sri Lankan consortium. Kröner, A. (ed.) Professional Paper 5, Geological Survey Department, Sri Lanka, pp 164-178.

Ramsay, J.G. (1967). Folding and fracturing of rocks. McGraw-Hills, New York.

Ranaweera, L.V. (2008). The Wanni-Highland Boundary Shear Zone of Sri Lanka: Field and Structural evidence, unpublished M.Phil. Thesis, University of Peradeniya, Sri Lanka.

Sajeev, K. and Osanai, Y. (2004) Ultrahigh-temperature metamorphism $\left(1150^{\circ} \mathrm{C}, 12 \mathrm{kbar}\right)$ and multistage evolution of $\mathrm{Mg}, \mathrm{Al}$ rich granulites from the central Highland Complex, Sri Lanka. Journal of Petrology, 45: 1821-1844. 
Sajeev, K., Osanai, Y., Connolly, J. A. D., Suzuki, S., Ishioka, J., Kagami, H. and Rino, S. (2007) Extreme Crustal Metamorphism during a Neoproterozoic Event in Sri Lanka: A Study of Dry Mafic Granulites. The Journal of Geology, 115: 971-974.

Sajeev, K., Williams, I.S. and Osanai, Y. (2010) Sensitive high-resolution ion microprobe $\mathrm{U}-\mathrm{Pb}$ dating of prograde and retrograde ultrahigh-temperature metamorphism as exemplified by Sri Lankan granulites. Geology, 16: 971-974.

Santosh, M., Maruyama, S. and Sato, K. (2009) Anatomy of a Cambrian suture in Gondwana: Pacific type orogeny in southern India? Gondwana Research, 16: 321-341.

Santosh, M., Tsunogae, T., Malaviarachchi, Sanjeewa P.K., Zhang, Z.M., Ding, H.X., Tang, L. and Dharmapriya, P.L. (2014) Neoproterozoic crustal evolution in Sri Lanka: Insights from petrologic, geochemical and zircon $\mathrm{U}-\mathrm{Pb}$ and $\mathrm{Lu}-\mathrm{Hf}$ isotopic data and implications for Gondwana assembly. Precambrian Research, 255: 1-29.

Schenk, V., Raase, P. and Schumacher, R. (1991) Metamorphic zonation and P-T history of the Highland Complex in Sri Lanka. In The Crystalline Crust of Sri Lanka, Part 1. Summary of Research of the German-Sri Lankan consortium. Kröner, A. (ed.), Professional Paper 5, Geological Survey Department, Sri Lanka, pp 150-163.

Schumacher, R. and Faulhaber, S. (1994) Summary and discussion of P-T estimates from garnet-pyroxene-plagioclase-quartz-bearing granulite-facies rocks from Sri Lanka. Precambrian Research, 66: 295-308.

Schumacher, R., Schenk, V., Raase, P. and Vitanage, P.W. (1990) Granulite facies metamorphism of metabasic and intermediate rocks in the Highland Series of Sri Lanka. In High-Grade Metamorphism and Crustal Anatexis. Brown, M. and Ashworth, J.R. (eds.) Allen and Unwin, London, pp 235-271.

Takamura, Y., Tsunogae., T., Santosh, M., Malaviarachchi, S.P.K. and Tsutsumi, Y. (2016) $\mathrm{U}-\mathrm{Pb}$ geochronology of detrital zircon in metasediments from Sri Lanka: Implications for the regional correlation of Gondwana fragments. Precambrian Research, 281: 434-452.

Tani, Y. (1999) Non-coaxial deformation of the Wanni Complex and its tectonic implication for the NeoProterozoic collision of the Wanni and Highland Complexes, Sri Lanka. Journal of Geological Society of Sri Lanka, 8: 17-42.

Tani, Y. (2002) Structural evolution of the high-grade gneisses in the Wanni Complex and its bearing on Proterozoic tectonics of Sri Lanka. Geological Survey and Mines Bureau, Sri Lanka, Professional Paper 8 (Gondwana Research Group, Memoir 7).

Tani, Y. and Yoshida, M. (1996) The structural evolution of the Arena Gneisses and its bearing on Proterozoic tectonics of Sri Lanka. Journal of Southeast Asian Earth Sciences, 14: 309-329.

Touret, J.L.R., Huizenga, J.M., Kehelpannala, K.V.W. and Piccoli, F. (2019) Vein-type graphite deposits in Sri Lanka: The ultimate fate of granulite fluids. Chemical Geology, 508: 167-181.

Tsunogae, T., Yang, Q. and Santosh, M. (2015) Early Neoproterozoic arc magmatism in the LützowHolm Complex, East Antarctica: petrology, geochemistry, zircon $\mathrm{U}-\mathrm{Pb}$ geochronology and $\mathrm{Lu}-\mathrm{Hf}$ isotopes and tectonic implications. Precambrian Research, 266: 467-489.

Vitanage, P.W. (1959) The geology of the country around Polonnaruwa. Geological Survey of Ceylon, Memoir 1, 1-75.

Vitanage, P.W. (1985) Tectonics and mineralization in Sri Lanka. Geological Society of Finland Bulletin, 57: 157-168.

Voll, G. and Kleinschrodt, R. (1991) Sri Lanka: Structural, magmatic and metamorphic develᄀopment of a Gondwana fragment. In The Crystalline Crust of Sri Lanka, Part 1. Summary of Research of the German-Sri Lankan consortium. Kröner, A. (ed.) Professional Paper 5, Geological Survey Department, Sri Lanka, pp. 22-51.

Willbold, M., Hegner, E., Kleinschrodt, R., Stosch, H.-G., Kehelpannala, K.V.W. and Dulski, P. (2004) Geochemical evidence for a Neoproterozoic magmatic continental margin in Sri Lanka Relevance for the Rodinia-Gondwana supercontinent cycle. Precambrian Research, 130: 185-198.

Yoshida, M., Funaki, M. and Vitanage, P.W. (1992) Proterozoic to Mesozoic East Gondwana: the juxtaposition of India-Sri Lanka-Antarctica. Tectonics, 11: 381-391.

Yoshida, M., Rajesh, H.M. and Santosh, M. (1999) Juxtaposition of India and Madagascar: A Perspective. Gondwana Research, 2: 449-462.

Yoshida, M., Kehelpannala, K.V.W., Hiroi, Y. and Vitanage, P.W. (1990) Sequence of deformation and metamorphism of granulites of Sri Lanka. Journal of Geosciences, Osaka City University, 33: 69-107. 